\title{
United Kingdom Education 1997-2001
}

\author{
Howard Glennerster
}

\section{Contents}

Introduction

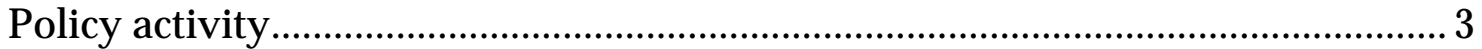

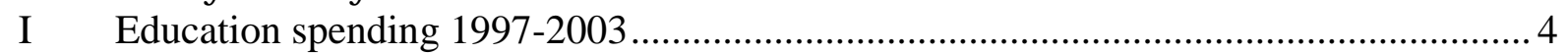

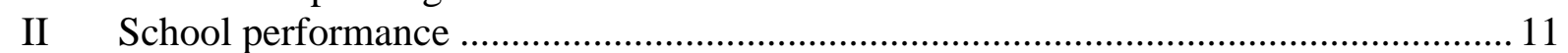

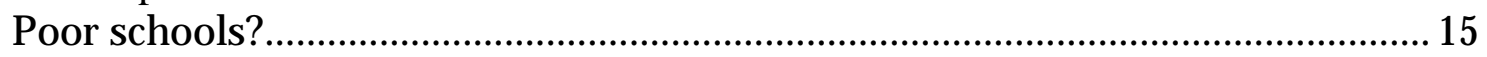

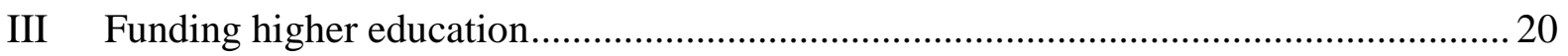

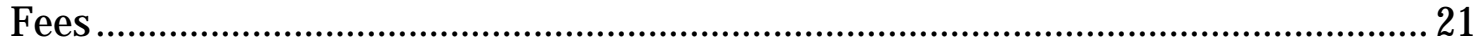

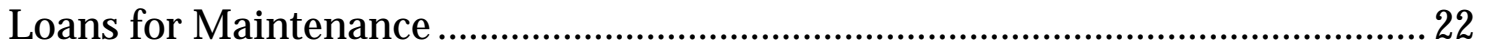

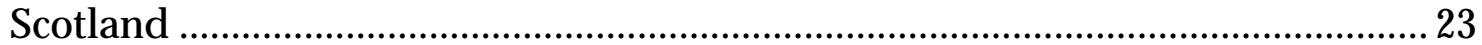

Central controls ............................................................................................. 23

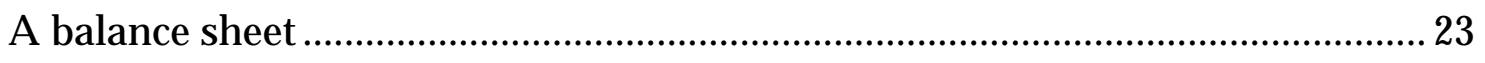

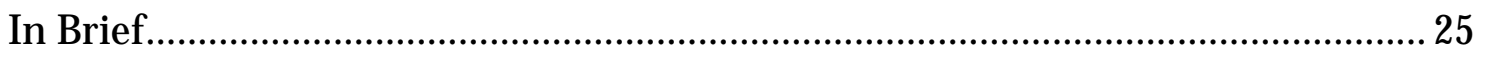

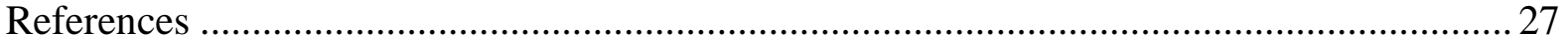

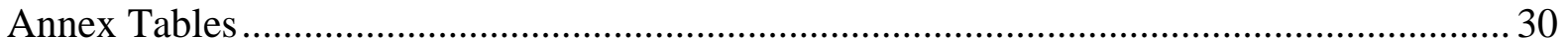

CASEpaper 50

November 2001
Centre for Analysis of Social Exclusion London School of Economics Houghton Street London WC2A 2AE CASE enquiries - tel: 02079556679 


\section{Centre for Analysis of Social Exclusion}

The ESRC Research Centre for Analysis of Social Exclusion (CASE) was established in October 1997 with funding from the Economic and Social Research Council. It is located within the Suntory and Toyota International Centres for Economics and Related Disciplines (STICERD) at the London School of Economics and Political Science, and benefits from support from STICERD. It is directed by Howard Glennerster, John Hills, Kathleen Kiernan, Julian Le Grand, Anne Power and Carol Propper.

Our Discussion Paper series is available free of charge. We also produce summaries of our research in CASEbriefs, and reports from various conferences and activities in CASEreports. To subscribe to the CASEpaper series, or for further information on the work of the Centre and our seminar series, please contact the Centre Administrator, Jane Dickson, on:

$\begin{array}{ll}\text { Telephone: } & \text { UK+20 7955 6679 } \\ \text { Fax: } & \text { UK+20 7955 6951 } \\ \text { Email: } & \text { j.dickson@lse.ac.uk } \\ \text { Web site: } & \text { http://sticerd.lse.ac.uk/Case }\end{array}$

(C) Howard Glennerster

All rights reserved. Short sections of text, not to exceed two paragraphs, may be quoted without explicit permission provided that full credit, including (C) notice, is given to the source. 


\section{Editorial Note and Acknowledgements}

Howard Glennerster is a Co-director of CASE and was Professor of Social Policy at the LSE from 1984 to 2001. A previous version of this paper was given at the economics section of the British Association for the Advancement of Science Conference at Glasgow on $4^{\text {th }}$ September 2001. I would like to thank numerous people who have commented on that version for their help.

\section{Abstract}

This paper reviews the achievements of the Labour Government's education policy between 1997 and 2001. Tony Blair claimed that his Government would make education a priority. The first part of the paper reviews the scale of education spending in relation to the economy at large and within the education budget. The second part of the paper looks at the productivity of schools. How far have the changes that have affected schools in the past ten years and the past five in particular affected the quality of school achievements? The paper suggests there have been significant improvements not just on average but especially in the gains made in poor areas and in the least good schools. Finally the paper discusses the funding of higher education, the introduction of income related loans to cover maintenance and up front fees. The paper concludes some serious errors were made in policy design. Even so the use of the Inland Revenue as the collection agency was a successful innovation and should be built upon.

Keywords: education productivity, higher education finance, Labour education policy

JEL number: H52 


\section{Introduction}

Tony Blair famously described Labour's priorities for government as "Education, Education and Education" in his Labour Party Conference speech of 1996. Five years later we are entitled to ask if that claim can be sustained.

Re-reading Tony Blair's speech it is difficult for an economist to disagree with the diagnosis, at least. The modern economy seems to have a voracious demand for highly skilled people. During the past decade the numbers of young people going onto higher education has doubled as a share of the age group. That represents a quite unprecedented growth in sheer numbers of graduates coming onto the labour market. You might have expected this to depress graduates' earnings relative to non-graduates. In fact, the gap widened in the 1990s and was wider than in 1974 (Machin 1999). The UK's levels of human capital endowment in the working population have been transformed in the past twenty-five years (see Table 1). In 1974 over half of all men between 16 and 69 had no qualifications at all and two thirds of women. Now the figures are 15 per cent and 19 per cent respectively. In 1974 only four per cent of the male work force had degrees. Now 16 per cent do. Only one per cent of women had degrees in 1974. Now 13 per cent do. But it seems this has not been enough. A recent OECD study (OECD 2001) showed that that higher education for women was more powerfully linked to higher earnings than in any other member country and a strong link for men. That suggests a continuing under supply of highly trained people. 


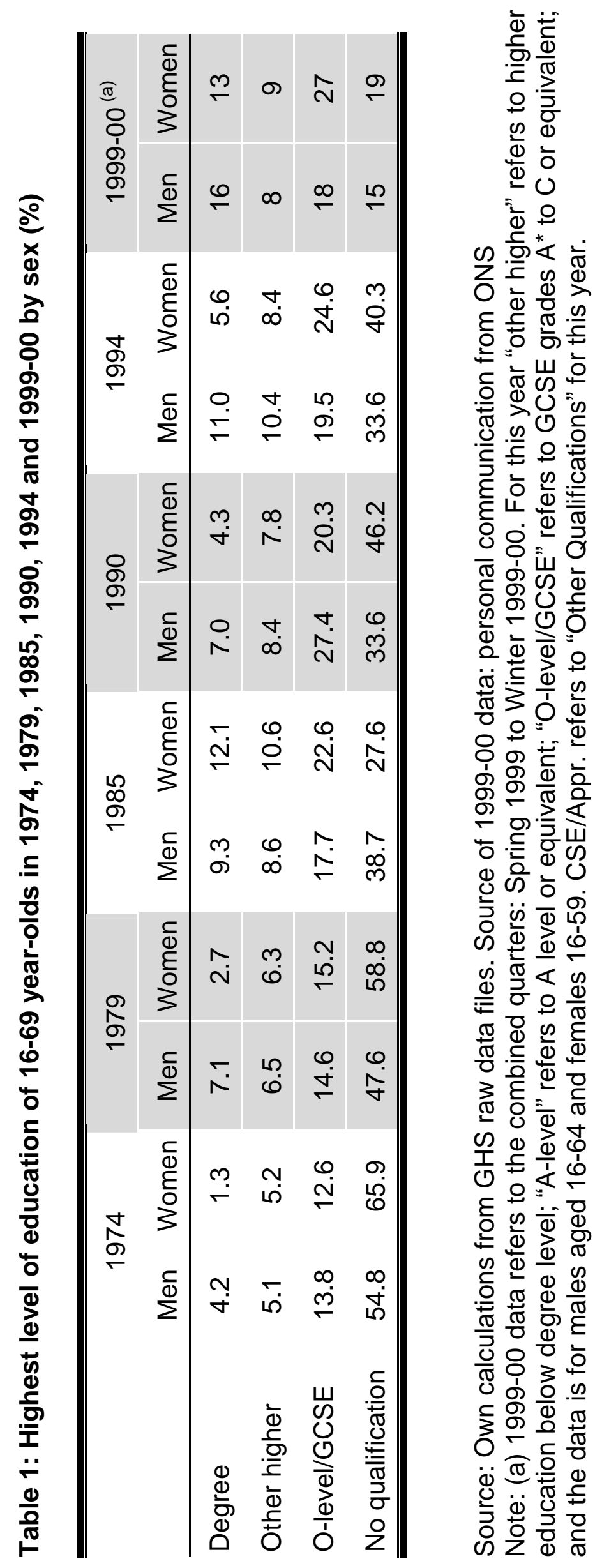


High levels of skill are not just necessary for a successful economy. They also impact on the distribution of income. The spread of skills helps determine the spread of incomes. A low skill labour force attracts and sustains firms that need a low skill mix. Low skills are related to high unemployment and to low pay (Layard et al 2001). High concentrations of those with poor skills in poor areas make it very difficult to rescue areas with high concentrations of poverty as our own work in the Centre for Analysis of Social Exclusion is showing (Lupton 2001). In short it is no accident that the UK has one of the greatest inequalities in educational performance in the advanced economies and one of the widest spreads in income distribution. Poor numeracy skills turn out to be one of the strongest predictors of poverty and low income in later life both in the US (Murname, Willett and Levy 1995). Poor qualifications and low achievement at school are strong predictors of social exclusion in later life on a range of measures even when all kinds of other factors like parental poverty are taken into account (Hobcraft 2000). As the Moser Report (1999) showed we have far more functional illiteracy in the UK than in other European countries.

In short, Blair and his government must be given full marks for getting the diagnosis right. If you want to eliminate child poverty and tackle social exclusion, the key is to raise the basic skills of those at the bottom and ensure an adequate supply of more highly educated people so that they do not get paid scarcity wages.

\section{Policy activity}

Here again if sheer legislative and administrative activity were our guide the Government would get high marks. There have been thirty-six major policy initiatives between 1997and 2001 and no doubt some I have missed! (See Annex 1) No less than a third have to do with some kind of initiative targeted at schools in poor areas or at those with low skills. Another third have to do with expanding apprenticeships, further and higher education. Much of the rest have to do with raising standards more generally.

Some of the most important changes will take a long time to bear fruit. The complete overhaul of the system for training 16-18 year olds the Foundation Modern Apprenticeships announced in 1997 will begin training 86,000 young people this year on top of 77,000 Advanced Modern Apprenticeship places, a scheme introduced by the last government. After the collapse of such training in the 1980s this looks a very important and welcome change but it is too early to judge outcomes. 
Pilot schemes to give grants to low income families to encourage those young people to stay on and reward good performance and attendance began in 1999 and will last for three years before legislation is introduced, learning from the experiments. That is something I have been urging for thirty years! But, again, too soon to see results. The trouble is that educational reforms take a decade to bear fruit - or many do. The Government committed itself to implement nearly all of the proposals in the Moser Report (1999). This puts in place a significant programme to improve the literacy and numeracy skills of adults who have missed out in their years of schooling. It is one of the most important and heartening things the government has done. Once more though it is far too early to see results.

So, high marks to the Government for trying to do things of which economists would approve. But some marks should be taken off for the sheer number and complexity of these initiatives. They produce administrative overload for those on the receiving end.

However, for an economist the real questions are - did the high policy priority manifest itself in more resources and what were the outcomes? Were there improved school outcomes not only for the average child but, especially, for the poor and low performers? Did the changes to funding higher education improve the efficiency and equity of the system?

So I shall concentrate on three issues in this paper:

$>$ overall funding;

$>$ school performance;

$>$ the funding of higher education.

\section{Education spending 1997-2003}

More money for schools is no guarantee of better results. There is a major controversy on just this point amongst economists (Burtless 1996). A recent paper in the Economic Journal (Gundlach, Woessman and Gmelin 2001) argues that in most OECD countries over the past twentyfive years, Britain included, pupil performance has remained stubbornly constant even though spending per pupil in real terms has risen. The authors follow Hanushek's (1997) conclusion on US schooling and talk about a 'productivity collapse' in OECD countries' schools. It is teachers, not pupils, who have benefited from increased education spending, they argue. So spending has risen but performance has not. Each teacher is 
costing more and producing the same. The output per pound spent on education has fallen.

The authors' figures only go up to 1995 . So what has happened since? Does the story still hold for the UK? Before we turn to look at school outcomes we need to examine what happened to education spending in the UK after 1995, and more particularly since $1997 ?$

It has proved extraordinarily difficult to get up to date figures for the UK. The last detailed breakdown of official figures for UK spending on education, at the time of the lecture, were for 1997/8! Devolution may be a good thing in many respects but it makes UK statistics a problem! With the help of some long suffering and helpful civil servants in Scotland, Wales, Northern Ireland and HM Treasury I have put together a time series of education spending series in real terms. It is consistent with that in the last edition of The State of Welfare (Glennerster 1998). ${ }^{1}$

It turns out that 1975/6 was the high water mark for public spending on education. It reached 6.5 per cent of the GDP in that year. To this we should add another 0.3 per cent private spending. The public spending cuts that followed steadily reduced that share until it reached 4.7 per cent in $1988 / 9$. Demography played a part but only a part of this story. University spending was held down despite a steady rise in the age group 'at risk', for example. See Table 2 for the breakdown of spending by sector. Then education's share began to rise again. It rose to 5.2 per cent in 1994/5. Faced with a decline in state spending private individuals responded by spending more themselves, pushing the total share of education spending in the economy back up to 6.1 per cent. Private spending came to add a fifth to the overall amount the nation as a whole spent on education. There are undoubtedly a complex series of factors lying behind this. Nevertheless, the basic fact has been that when the state has cut back its spending below the rate at which incomes are rising, after a short time lag private spending has risen to compensate, though not of course the benefiting the same people. The percentage of the population going to private schools has not increased. (See Annex Table 3.) What seems to be happening is that parents who have children

In fact the Treasury series for education's share of the GDP is not consistent with the Office of National Statistics in the past few years. I am told that this is because the two bodies use a slightly different definition of education! For recent years I have stuck to the Treasury definition since the Treasury's figures are more up to date. The differences only amount to 0.2 per cent of GDP and the trends are the same. 
at private schools are prepared to spend more in fees to keep increasing their children's standard of schooling. Fees are rising by six per cent a year in cash terms or 3.5 per a year in real terms (ISIS 2001). That compares with a virtual standstill in state school spending per pupil in the mid 1990s as we shall see. More of parents' money is also going to support their children's higher education and more is being spent on privately and publicly provided training courses.

The public spending recovery was to be short lived. From 1995 public spending on education slipped as a share of the GDP. That began under the Conservatives and, given the Labour Government's determination to keep to the Conservative plans in 1997 it went on falling. In 1998/9 and 1999/2000 it fell to 4.5 per cent - lower than in the depths of the Thatcher cut backs and the lowest figure since the early 1960s (Glennerster 1997 for earlier figures).

Essentially what happened was that levels of spending in 'real terms' remained static while the GDP rose. However, the measure of 'real terms spending' as used by the Treasury merely takes into account the rise in general inflation. If incomes in general are rising as the GDP rises, the pay of teachers and other staff needs to rise too otherwise the relative quality of teachers that can be recruited will fall.

Public spending did begin to rise again in 1999. The figure for this financial year is 5.0 per cent and, according to the Treasury as a result of the last Comprehensive Spending Review it will be 5.3 per cent of GDP by 2003/4 (HM Treasury 2000). Even that would only put state education spending back to the levels of the early 1990s! See Table 2.

So by no stretch of the term "priority" could it be said to have applied to state education spending in the first two years of the Labour Government. Within that total spending on nursery and primary schools did continue to rise after 1997 at the same time as there was a fall in the size of that population. This is where the Government put its priority. The Government was able to use that demographic breathing space to extend pre school education to all four year olds whose parents wanted it. As a result the percentage of three and four year olds in school rose from 58 per cent in 1996/7 to nearly 64 per cent in 2000 for the United Kingdom as a whole. This still leaves us with a lower participation rate than most European countries for 3-4 year olds but a higher one than North America (See Annex 3 Tables 1 and 2). 


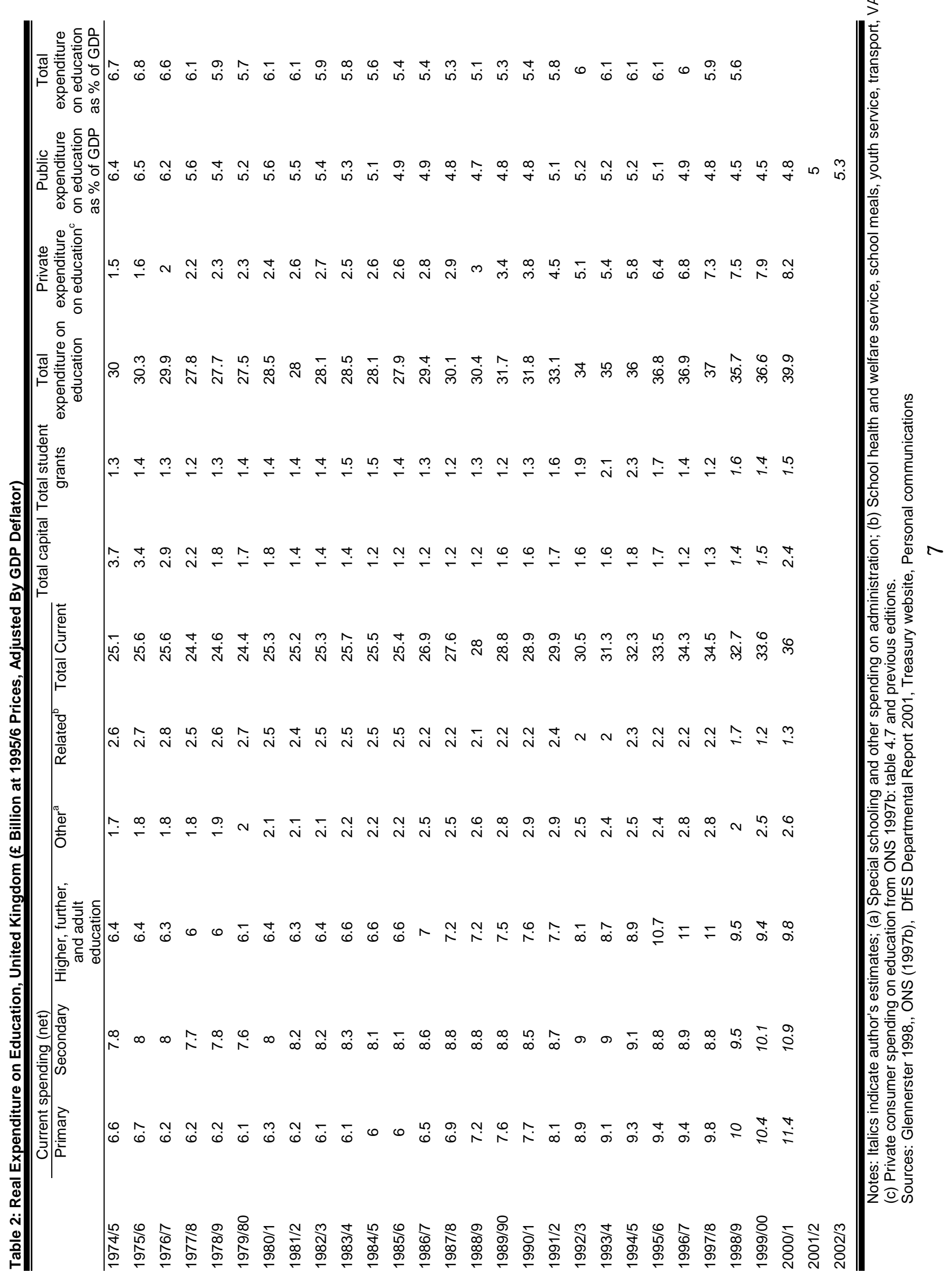




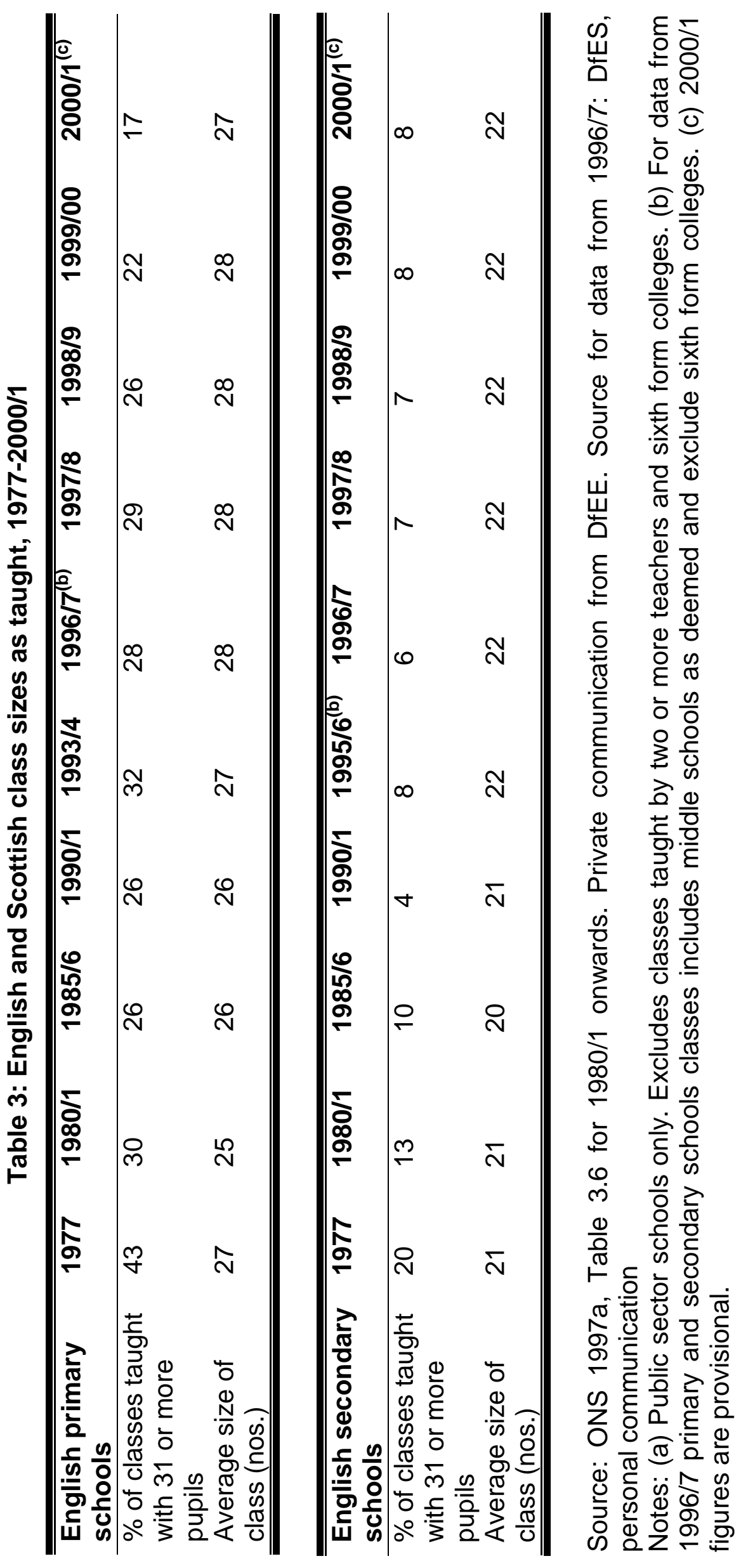




\begin{tabular}{lcccc}
\hline \hline Scottish primary schools & $\mathbf{1 9 9 7 / 8}$ & $\mathbf{1 9 9 8 / 9}$ & $\mathbf{1 9 9 9 / 0 0}$ & $\mathbf{2 0 0 0 / \mathbf { 1 }}$ \\
\hline \% of classes taught with: & & & & \\
1-20 pupils & 12 & 11 & 12 & 14 \\
$21-30$ pupils & 68 & 71 & 73 & 72 \\
31 or more pupils & 21 & 19 & 15 & 14 \\
Average size of class (nos.) & 25 & 25 & 25 & 24 \\
\hline \hline
\end{tabular}

\begin{tabular}{lccccc}
\hline \hline $\begin{array}{l}\text { Scottish secondary } \\
\text { schools }\end{array}$ & $1996 / 7$ & $1997 / 8$ & $1998 / 9$ & $1999 / 00$ & $2000 / 1$ \\
\hline Pupil/teacher ratio & 13 & 13 & 13 & 13 & 13 \\
\hline \hline
\end{tabular}

Source: Personal communication from Scottish Executive

Note: (1) secondary school class information is not available due to the structure of the curriculum; (2) primary school class information is not available prior to 1997/8; (3) primary information is for single stage classes only; (4) classes of 30 or more with 2 teachers have been removed from the data, except in 1997/8 where this was not possible.

The number of primary classes in England with over 30 pupils was reduced from 28 per cent in 1996/7 to 17 per cent in 2000/1. However, the average size of class barely changed - classes presumably fell from just over 30 to just under the magic number. See Table 3 above. There is a similar trend in Scotland, though class sizes were lower there to start with.

The size of the secondary school population on the other hand continued to rise. Nearly all the extra funding there went to teach the extra pupils. It was not until 1999/2000 that real per pupil spending in secondary schools rose above the 1995/6 levels in England and a year later in Scotland. See Table 4. From then on the government are promising a much larger boost in per pupil spending for both primary and secondary schools up by over a quarter in real terms by 2003/4. Welcome though that is it has been a long time coming.

State funding per head for further and higher education fell steadily through the 1980s and early 1990s (Glennerster 1998). It has continued to do so. Per pupil public support for higher education fell by ten per cent between 1995 and 1997 and has only roughly stabilised since. See Table 5. To this public funding the Labour Government added the additional fees richer students were required to pay after autumn 1998. More about that later. 


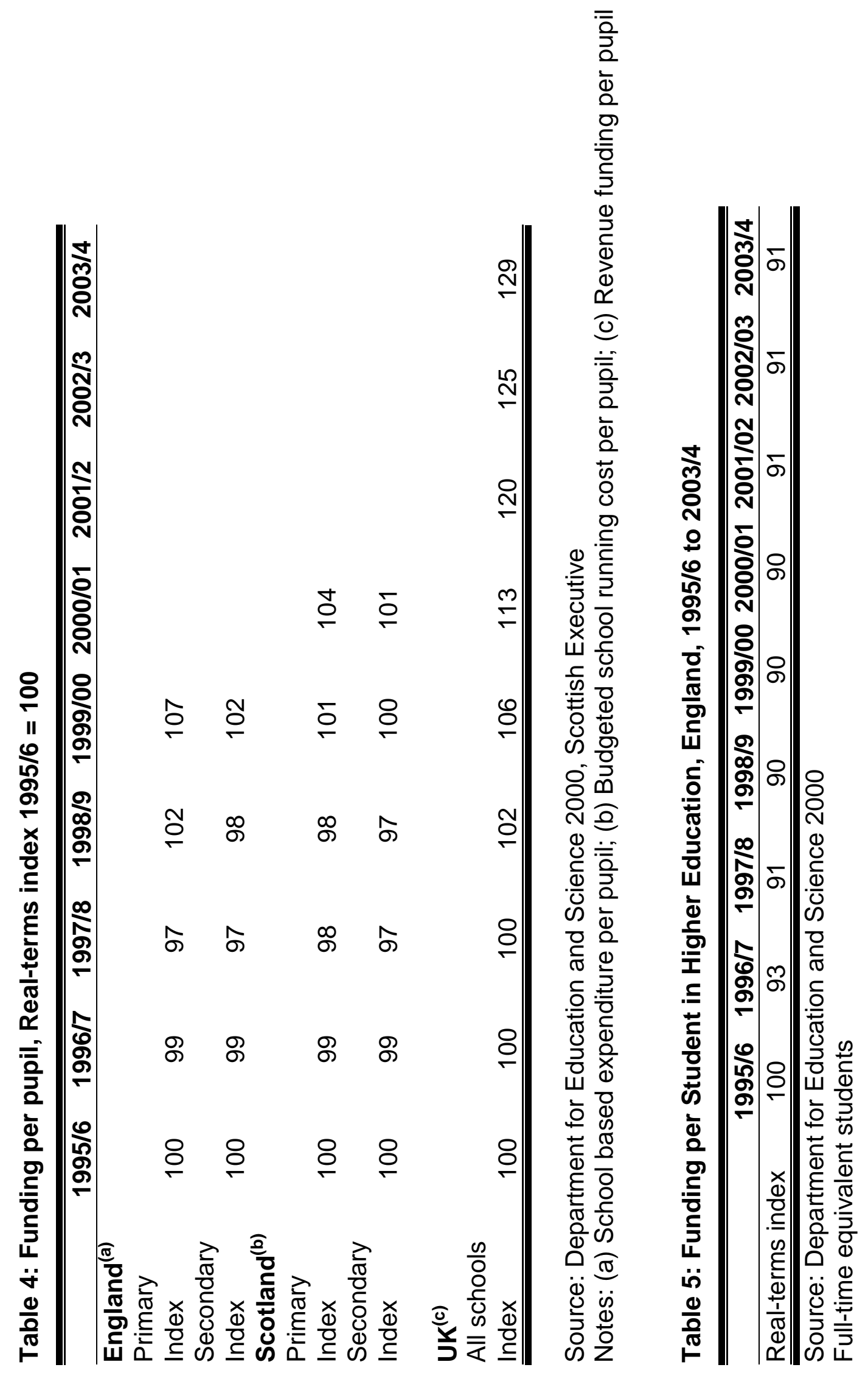




\section{School performance}

So schools gained little by way of extra resources between 1995 and 1998/9. What of their performance? The criticism levelled by the authors of the Economic Journal paper and their American predecessors is that state schools perform badly because they exist in a competitive free environment and have no external form of performance measurement to act as an external spur. Now neither of these general points any longer holds for the United Kingdom.

Schools, and primary schools in particular, have been subject to the biggest change in the pattern of incentives that govern them for a generation. Much of the rationale for these big changes came from economists. They argued that control of school resources should be devolved to the level of the school. That would permit decisions about staffing, the mix of staff and technology, the choice of suppliers and control of maintenance work could all be done where the knowledge about the local situation was richest and where performance could be monitored and corrective action taken most effectively (Chubb and Moe 1990; Ladd 1996; Burgess 1997). When a child kicks a ball through a window it is no longer necessary to send a request to County Hall for someone to appear six months later to mend it. An odd job man down the road can do it that night.

On the other hand knowledge about relative standards your pupils were achieving or exactly what to teach and how best to do it may not lie at the level of the individual class room teacher- the old British tradition. Hence the case for a National Curriculum and national tests which set relative standards and, more recently, prescribed literacy and numeracy hours. It is all too easy and understandable for a teacher faced with a difficult class or a subject she or he is not too confident in to spend time on other tasks. As my wife, who used to teach maths to intending primary school teachers, once observed - "Most of my students are scared stiff of maths and take every excuse not to teach it if they can."

On its own that was not enough. There had to be some incentives for schools to perform on and not inside their production possibility frontier. That was to be achieved by a whole series of pressures schools were put under by the previous government - greater parental choice backed up with pupil based funding (quasi market vouchers), the national testing of pupils and the publication of results. It is certainly true, as many parents complain, that they cannot get their children into 
the most popular schools. They do not expand to meet demand any more than the top private schools do. But the threat of parents taking away their child or not choosing a school if it is performing badly, and hence not bringing their money with them, does act as a real incentive to worry about the schools academic results. This has both good and bad consequences as we discuss later. But the lack of an efficiency motive, of which the authors of the Economic Journal paper complained, is no longer true. The full system of testing pupils at 7, 1114 and 16 did not come into effective force until $1995 / 6$.

Taken together, and for good or ill, this was a series of measures that derived to a significant extent from micro economic theory. It marked a profound change in the assumptions under which schools operated. The interesting thing for this paper is that, unlike in health, where much of the quasi market reforms were diluted by the incoming Labour Government, the Thatcher education reform package was retained and, if anything, strengthened. More of the budgets were devolved to schools. There was no let up in performance testing or publication of results and on top of this an experiment begun under the previous administration was introduced nationally and extended to mathematics - literacy and numeracy hours. These set recommended ways of teaching these subjects for a given period of time each day.

Before examining what has happened since 1995 and 1997 it is worth reminding ourselves what had been the record of pupil performance in British schools in the previous thirty years. We only have comparable results over time for maths. That means we do not know how far changes in maths achievements are representative. There are difficulties in measuring skill levels over time - syllabi change. But maths is a core skill and the basics can be tested and do not change all that much. With all those qualifications what these surveys suggest is that there had not been any significant improvement in basic maths capacity of early years secondary school children since the mid 1960s, indeed, a small decline. They also suggested that the poor performance of the very lowest achievers that has characterised British education for so long had continued.

More recent trends in science scores showed some improvement. The number passing O level, GCSE and A level have improved over the same period but GCSE significantly changed the nature of school leaving exams and the numbers gaining A level are as much affected by staying on rates as basic skill knowledge. (For a summary of the trends, sources and caveats see Glennerster 1998). So, despite the caveats the balance of evidence suggests that basic maths skills possessed by early 
years secondary school children had not improved for a long period up to 1995. It is against that background that the results of the national attainment tests are so surprising.

These tests are designed to see how far pupils achieve certain standards deemed necessary to be a functioning citizen. Levels of expected achievement are set for ages 7,11, 14 and 16 (see Figure 1).

Figure 1: National Achievements Tests

\begin{tabular}{lcc}
\hline \hline Key Stages & Levels & Ages \\
\hline 1 & $1+2^{\star}$ & 7 \\
2 & $3+4^{\star}$ & 11 \\
3 & $5^{\star}+6$ & 14 \\
4 & $7+8$ & GCSE \\
\hline \hline
\end{tabular}

Source: DfES Statistics Bulletins: 04/98; 08/99; 03/00; 04/01

* expected level of achievement

Table 6 shows the percentage of pupils reaching the expected levels at each age in the tested subjects.

The overall pattern of results is very clear. There has been a steady improvement at all levels and in each subject, apart from the occasional blip, across all five years. The improvements have been particularly striking at level four - the end of primary school. For example, by the end of primary school the percentage of pupils gaining the expected levels of competence in maths was 70 per cent in 2001. This was up from 45 per cent in 1995 . The pace of improvement quite naturally slowed in the past year but was continuing across the board at level 2, in writing and science at level 4 and in maths at level 5. Reading and maths scores had fallen back slightly at level 4 . Nevertheless, the picture over the whole period remains remarkable, if we can believe the figures, a point we discuss more below.

It is impossible to assign relative weights to any one of the measures we listed previously but in combination they do seem to have produced a step change in pupil outcomes at least in primary schools, and this despite minimal extra resources given to schools in the period in question.

Table 6: Overall Performance 1995-2000, Maintained Schools, \% Reaching Expected Levels 


\begin{tabular}{llllllll}
\hline \hline & $\mathbf{1 9 9 5 ^ { ( \mathbf { a } ) }}$ & $\mathbf{1 9 9 6 ^ { ( \mathbf { b } ) }}$ & $\mathbf{1 9 9 7 ^ { ( \mathbf { c } ) }}$ & $\mathbf{1 9 9 8}$ & $\mathbf{1 9 9 9}$ & $\mathbf{2 0 0 0}$ & $\mathbf{2 0 0 1 ^ { ( \mathbf { d } ) }}$ \\
\hline Level 2 & & & & & & & \\
Reading & 78 & 78 & 80 & 80 & 82 & 81 & 84 \\
Writing & 80 & 79 & 80 & 81 & 83 & 84 & 86 \\
Maths & 79 & 82 & 84 & 85 & 83 & 90 & 91 \\
Level 3 & & & & & & & \\
Reading & 49 & 57 & 67 & 71 & 78 & 83 & 81 \\
Writing & - & - & 53 & 52 & 54 & 55 & 57 \\
Maths & 45 & 54 & 62 & 58 & 69 & 72 & 70 \\
Science & 70 & 62 & 69 & 69 & 79 & 85 & 87 \\
Level 5 & & & & & & & 64 \\
English & 55 & 57 & 57 & 65 & 64 & 64 & 64 \\
Maths & 58 & 57 & 60 & 59 & 63 & 65 & 66 \\
Science & 56 & 57 & 60 & 62 & 55 & 69 & 66 \\
\hline \hline
\end{tabular}

Source: DfES Statistical Bulletins: Table 19,4/98; Table 18, 4/01, SFR40 2001 Notes: (a) participating schools $90 \%$; (b) $95 \%$; (c) $90 \%$; (d) provisional With the exception of a temporary drop once in science at level 5 and very marginally in Maths level 4 and 5 there has been consistent improvement, some modest, some very substantial, especially at level 4 .

We should, however, be properly sceptical.

$>\quad$ Is it just that children and teachers have learned how to do tests and there is no real underlying improvement? The fact that the improvements have lasted as long and been so large makes that a doubtful excuse.

$>\quad$ Perhaps a large number of heads are cooking the books. I find that difficult to believe even if the odd case has emerged.

More firm counter evidence may be the tests administered to a national sample of children aged 13 in 1999 as part of a regular international survey of achievement - the International Association for the Evaluation of Educational Achievements reported in (OECD 2001). Maths and science scores in 1999 did not show up as statistically different compared to those of 1995. The range of skills measured in this international survey are not the same as the national tests in England. They apply to secondary schools. They only apply to a sample of schools and the incentives children have to try to do well in them is minimal. The national assessment tests matter to the teachers and the pupils. Finally, the 
progress we reported above was particularly strong for primary and not secondary schools. Nevertheless, future results of this international survey must be watched with care.

\section{Poor schools?}

One of the fears critics of the new system of school choice and school funding expressed (Glennerster 1991) was that it would increase the gaps between schools and especially those in richer and poorer areas. In practice the combined effects of all the strategies we have described does not seem to support this fear though far more could be done to guard against possible perverse effects.

Table 7 shows what has been happening in the median school in each year (that is the middle school if all were ranked from top to bottom). But it also shows the scores of the school just in the top quarter and the school just in the bottom quarter of schools the $75^{\text {th }}$ and the $25^{\text {th }}$ percentile schools. We show the results at Key Stage 2 or at eleven years in Table 7. Comparable results for the other levels are shown in the Annexe Tables. Detailed figures of this kind are only available up to the year 2000.

If anything there has been a greater improvement by the lowest performing schools. This is again especially evident in the primary schools. The gap between the top and bottom quartile school in maths at age eleven was 32 per cent in 1997 and 25 per cent in 2000. It narrowed from 30 to 24 points in English and from 28 to 19 points in science.

The narrowing at the end of secondary school is nothing like as great, as can be seen from Annexe tables 4 and 5. However, the effect is still there. By the age of fourteen the gap in English between the top quartile school and the bottom was 32 points. It was 26 points in 2000 . There was little change in the gap in maths and science - merely an improvement across the board. But there was no widening gap. 
Table 7: Gap Between the Scores Of Schools 1995-2000 (Maintained Schools)*

\begin{tabular}{lccccc}
\hline $\begin{array}{l}\text { Key stage 2: 11 years } \\
\text { Level 4+ }\end{array}$ & $\mathbf{1 9 9 5}$ & $\mathbf{1 9 9 7}$ & $\mathbf{1 9 9 8}$ & $\mathbf{1 9 9 9}$ & $\mathbf{2 0 0 0}$ \\
\hline $\begin{array}{l}\text { English } \\
75^{\text {th }} \text { percentile }\end{array}$ & 65 & 78 & 80 & 84 & 88 \\
$\quad$ Median & 50 & 67 & 67 & 73 & 78 \\
$25^{\text {th }}$ percentile & 35 & 52 & 52 & 61 & 64 \\
Maths & & & & & \\
$75^{\text {th }}$ percentile & 63 & 78 & 75 & 83 & 85 \\
$\quad$ Median & 47 & 65 & 61 & 72 & 74 \\
$25^{\text {th }}$ percentile & 31 & 50 & 44 & 59 & 60 \\
Science & & & & & \\
$75^{\text {th }}$ percentile & 88 & 86 & 85 & 92 & 96 \\
$\quad$ Median & 76 & 73 & 73 & 83 & 88 \\
$25^{\text {th }}$ percentile & 60 & 58 & 57 & 71 & 77 \\
\hline \hline
\end{tabular}

Source: DfES Statistical Bulletins: Table 19, 4/98; Table 18, 4/01

${ }^{*}$ Figures are for the $75^{\text {th }}$ percentile school, median and $25^{\text {th }}$ percentile school. They show the \% of pupils in these schools who have reached the expected level.

The gap between the top and bottom schools narrowed in each subject.

Table 8: Interquartile Range Of Schools - \% Of Pupils Reaching Expected Level

\begin{tabular}{lccccc}
\hline $\begin{array}{l}\text { Key stage 2: 11 years } \\
\text { Level 4+ }\end{array}$ & 1995 & 1997 & 1998 & 1999 & 2000 \\
\hline English & 30 & 26 & 28 & 23 & 24 \\
Maths & 32 & 28 & 31 & 24 & 25 \\
Science & 28 & 28 & 28 & 21 & 19 \\
\hline \hline
\end{tabular}

The gap between the top and bottom schools narrowed in each subject.

Perhaps even more striking is the fact that the schools with a high number of pupils on free school meals (over 40 per cent) have been catching up with the schools where less than five per cent of pupils have free meals. Free school meals take up, as an indicator of poverty, has been highly correlated with poor school performance. If we take the median school in each group as the indicator we can see that in 1997 only 37 per cent of children at eleven had reached their expected levels of performance in English and Maths. (See Table 9). By 2000 that figure had increased to 55 and 53 per cent with science achievements up from 45 to 70 per cent of children. These are extremely encouraging results 
though we only have to look at the figures for key stage three to be depressed again. In 1997 no child in these schools reached the expected levels in either English or Maths or Science. No one did in English in 2000 and only 13 and 14 per cent in Maths and Science. So in these schools in poor areas a huge amount still needs to be done.

Table 9: Poor Schools

\begin{tabular}{lccc|ccc}
\hline \hline Median schools in group & \multicolumn{3}{c|}{ Rich } & \multicolumn{3}{c}{ Poor } \\
\cline { 2 - 7 } & $\mathbf{1 9 9 7}$ & $\mathbf{1 9 9 9}$ & $\mathbf{2 0 0 0}$ & $\mathbf{1 9 9 7}$ & $\mathbf{1 9 9 9}$ & $\mathbf{2 0 0 0}$ \\
\hline Key stage 1 & 91 & 93 & 94 & 62 & 67 & 70 \\
$\quad$ Reading & 92 & 94 & 94 & 62 & 68 & 71 \\
Writing & 94 & 91 & 98 & 70 & 76 & 81 \\
Maths & & & & & & \\
Key stage 2 & 80 & 87 & 89 & 37 & 48 & 55 \\
English & 79 & 85 & 86 & 37 & 49 & 53 \\
Maths & 85 & 92 & 95 & 45 & 60 & 70 \\
Science & & & & & & \\
Key stage 3 & 75 & 84 & 83 & 0 & 8 & 0 \\
$\quad$ English & 78 & 82 & 83 & 0 & 9 & 14 \\
$\quad$ Maths & 79 & 78 & 79 & 0 & 5 & 13 \\
$\quad$ Science & & & & & & \\
\hline \hline
\end{tabular}

Source: DfES Statistical Bulletins: Table 19, 4/98; Table 18, 4/01

Rich $=$ up to $5 \%$ with free school meals; Poor $=$ over $40 \%$ with free school meals

Certainly our study in CASE of the views of parents in very poor areas about their services supports these results (Mumford 2001). Nearly half felt their primary schools, in particular, were getting better. The reasons they articulated included some special measures taken to improve a failing school, the introduction of home work, after school activities, improvements to the physical building, hearing about improved academic results, the expulsion of bullies and increasing sensitivity to the needs of ethnic minority populations. 
Table 10: Difference In \% Of Pupils Reaching Expected Levels In Rich And Poor Schools

\begin{tabular}{llll}
\hline \hline & $\mathbf{1 9 9 7}$ & $\mathbf{1 9 9 9}$ & $\mathbf{2 0 0 0}$ \\
\hline Key Stage 1 & & & \\
Reading & 29 & 26 & 24 \\
Writing & 30 & 26 & 23 \\
Maths & 24 & 15 & 17 \\
Key Stage 2 & & & \\
English & 43 & 39 & 34 \\
Maths & 42 & 36 & 33 \\
Science & 40 & 32 & 25 \\
Key Stage 3 & & & \\
English & 75 & 76 & 83 \\
Maths & 78 & 73 & 69 \\
Science & 79 & 73 & 66 \\
\hline \hline
\end{tabular}

Source: DfES Statistical Bulletins: Table 19, 4/98; Table 18, 04/01

A slow improvement in poor schools at Key Stage 1 and 2. A long way to go at Key Stage 3 . Rich $=$ up to $5 \%$ with free school meals. Poor $=$ over $40 \%$ with free school meals. Median schools in group used for analysis

What caveats should we enter about these figures?

First, it will be objected that there is a ceiling affect. The schools at the top are already near the targets. They have little room for improvement. The schools at the bottom have nowhere to go but up. The problem with that objection is that it also held for the thirty years in which no improvement took place. This is a real change.

It is true that the top schools may be doing even better beyond the expected levels. Inequality may not have improved. This is the old argument between relative and absolute poverty. Both matter. And to my mind absolute poverty, or in this case functional illiteracy, matters more. It may be that in the rich schools some pupils are much quicker at reading their Harry Potter or using the internet in ways that go beyond the scores set in the national tests. But that was not what the government set out to achieve. It wanted to raise all children's skills to a minimum level. What matters is that there has been a real improvement in poor children's basic skills, their capacity to function in modern society. 
So to return to Gundlach et al's paper in the Economic Journal earlier this year, the "productivity collapse" they describe hardly seems to fit the UK in the past five years. Spending stagnated but output grew in a way unseen for thirty years. It could be called a "productivity explosion." The reason seems to be that the combination of reforms in the past decade have made a difference. The reforms include: devolved budgetary responsibility, the setting of national standards, some degree of parental exit power with money following pupil and school choice and some requirement by the centre to follow 'good practice' - the numeracy and literacy hours. It is impossible to disentangle the precise contribution of each element of these reforms. They mostly happened together and are interdependent. Some reforms happened earlier notably the introduction of GCSE. The quasi market elements probably most affected secondary schools and the numeracy and literacy hours only affected primary schools.

One on my worries early on (Glennerster 1991) was that such competition would merely induce cream skimming or competition for the better pupils rather than improved efficiency. There is conflicting evidence on cream skimming (Gorad and Fitz 1998; Gerwitz, Ball and Bowe 1995). However, not all the competition to attract better pupils has been successfully achieved by the better schools. The incentives to undertake it are greatest for the least well performing schools. Research done in poor neighbourhoods by CASE suggests that one response of head teachers in poor areas has been to go out and actively woo a wider mix of pupils by selling their school beyond its traditional recruitment area. This has plausibly had spin off, or peer group effects, on poorer pupils in such schools, as well as raising the average score of the school by the mere presence of more able or motivated students. We know that less able pupils gain more from a mixed ability environment than able pupils lose by leaving a more select environment (Robertson and Symons 1996). In short we need to know a lot more about the dynamics that have lain behind these changes in pupil performance.

It is clear, however, that many of the most deprived schools face very little effective competition. Few parents in very poor areas seek to send their children to schools beyond their most local one. The exit sanction is weak. Moreover, there are still incentives for schools to cream skim. Value added scores for schools in the league tables remain very slow in coming. The Government has not done enough to compensate schools for the extra demands that poorer performing or difficult pupils put on the school. Ideally, a school should be indifferent between accepting a child with differing potential or problems compared to 
another pupil. If it were to receive sufficient additional rewards for taking difficult pupils that could be achieved. We have to find a more rigorous and evidence based allocation to schools in deprived areas.

\section{Funding higher education}

One of the most fundamental changes the Labour Government made was in the funding of higher education. Here they had the opportunity to put right the previous government's mistakes and failed. Indeed, the very things they got right about schools they got wrong with higher education. There now seems some prospect of a rethink if the papers are to be believed.

Economists have been advocating some kind of student loan scheme as a way of funding higher education ever since Milton Friedman's proposals in 1962. The previous Conservative Government had partially gone down this road. The scheme forgave loan repayments from the poor but had many of the characteristics of a mortgage loan and it only covered some of the costs of maintenance. Others had long argued against mortgage type loan schemes. They would deter poor students and be unfair on later low earners. Much better to have fully income related repayments and those who did well out of higher education should repay at least some of the cost of tuition. My own first published paper as a new lecturer at the LSE back in 1968 (Glennerster et al 1968) suggested a Graduate Tax - using the income tax system as the repayment vehicle. I saw it as a way to fund a rapid expansion of higher education without diverting large sums into the pockets of the present and future middle classes! For a time it seemed as if the Labour Government was about to implement that idea.

After a major enquiry into funding higher education the Dearing Committee reported in 1997 just after the Election (Dearing 1997). It recommended that graduates should make a contribution equivalent to 25 per cent of the average cost of their tuition while they were in work on some income contingent basis. (Recommendation 79) This was much in line with what many economists had been recommending and was similar to the scheme the Australian Government had introduced in 1989.

In the end the UK Government only partially implemented these ideas and did so in a way that was both unpopular, misconceived and only raised a tiny amount of cash. 
The first leg of the government's plan was to transform the maintenance grant into a more generous income contingent loan made through the Student Loans Company that would be repaid through the Inland Revenue. This minimised dangers of default and provided an efficient repayment mechanism linked to an individual's taxable capacity and their benefit from the system. This was a major breakthrough. For years the Inland Revenue and the Treasury had resisted this idea. It meant that more generous support could be given to students without the full cost appearing as public expenditure. Since part of the risk was being taken by the Student Loans Company and students would be paying for part of the cost of the loan future burdens on the taxpayer would be minimised. That was all before the days of resource accounting. Now the effect will be more transparent and the benefits of the new system will be that much greater. Thus far so very good.

However, the Government then made a number of crucial errors (Barr 2001).

\section{Fees}

It needed cash for the universities then and there. They were in a bad way financially. Their cash per pupil had been cut by ten per cent as we have seen. Some were on the edge of bankruptcy. For them to receive deferred fees from students several years later would have been no help. The Treasury was not prepared to accept that increased support for universities in the interim should not count as public spending despite the increased revenue stream such a scheme would engender. So the government went for means tested fees paid up front. That extra could then be paid directly to universities without raising public expenditure. Poor students would be exempt but parents of the richest third would pay $£ 1000$ a year. At a stroke this got the whole scheme a bad name.

$>\quad$ It went back on the principle of undergraduate education being free at the point of use. The hostility to breaking this principle has over lain the other much more sensible system of income contingent loans for maintenance costs. The fact that fees are not paid by children of poor parents is something very few seem to realise. So a bad signal is sent out despite the attempt to help the poor.

$>\quad$ Precisely because such a move was unpopular the fee level was kept low and it only applied in full to a minority of students. As a consequence the sums raised in fees were tiny in relation to universities' needs. The total revenue from undergraduate 
statutory fees amounted to only $£ 350$ million in England in $2001 / 2$, rising to $£ 400$ million in 2003/4. (Hansard Written Answer 9 July 2001). Total spending on higher and further education was running at $£ 10$ billion at the turn of the century See Table 2 .

Nor could institutions vary them to reflect the different costs of teaching in different institutions or to compete on quality and cost. Fees did not vary by subject though some subjects cost five times as much as to teach as others. The student is indifferent between an expensive engineering course and a cheap course in maths and computing which are the skills many employers are looking for in engineering students!

$>\quad$ It relied on parents' willingness to pay and not on students' own decisions about whether the price was worth paying at some future date.

$>$ Risks of failure or poor performance faced by working class students do appear to be greater than for middle class students (Naylor et al 2001). There were other ways to address this problem if policy makers wished to than a means tested fee. Maintenance grants for six formers from low income families see below might be a way forward.

\section{Loans for Maintenance}

The new way to fund student maintenance, a loan repaid through later tax payments, also had major weaknesses.

$>\quad$ Critically, the government set a nil real rate of interest. The sum to be repaid was the amount borrowed indexed for prices and that was all. This meant two things.

- When the Treasury calculates the cost of the loans scheme to public expenditure the loan subsidy element is a large one. It amounts to about a third of the cost of the scheme (Barr 2001). The potential benefits are thus much reduced.

- It encourages rich parents to use the scheme. Who after all would turn up the chance of an interest free loan if they can help it? Such, at least, was American experience of nonmeans tested cheap loans for students. It increases the public spending cost of the scheme to no good purpose.

Partly to offset this tendency, the availability of the loans is limited. There is a means tested ceiling to the loans available dependent on parental income and scholarship income. This makes the whole scheme vastly more complex than it need be. Instructions to local authorities on how to operate the scheme 
amount to 150 pages. There is a disincentive for universities to offer scholarships to poor students and much else.

$>\quad$ The limits to the amount students could "borrow" were too low especially for students living in high cost areas.

The threshold at which repayments begin is too high. Too many do not repay or repay late. Taken together with the nil interest this reduces the revenue still further. To put it another way, for the same revenue you could set a lower repayment percentage.

\section{Scotland}

The fees issue became a major element in the Scottish elections and after the coalition Government was formed there the Scots went nearer to producing a sensible scheme. Fees would be paid back after graduation through the same mechanism as the maintenance loan - the Inland Revenue. Again, so far so good.

However, the scheme still uses a nil real interest rate and has a much higher threshold than in England $£ 17,500$ nearly twice the English level. Thus the Scots get even less relief to their public spending limits than the English.

\section{Central controls}

Along with a complex and centrally controlled system of funding has gone a steady increase in other kinds of "quality" control largely concerned with process and not with outcome. For the last Teaching Quality Assessment Review I remember weighing the material we, as a single department had been asked to submit. It came to about a fifth of a ton!

\section{A balance sheet}

The good thing is that we now have in place, especially in Scotland, an effective mechanism for collecting income contingent repayments for both maintenance grants and fees. The bad thing is that this mechanism has been tainted by the introduction of up front fees and has not been implemented in such a way as to maximise the revenue and public spending gains that could have accrued. The potential available revenue could be used to enhance access from poorer groups. So far as we can see the changes in student support in the 1990s has not worsened differential social class access. See Table 11. This may come as a surprise, given the bad press both loans and fees have had. The reasons may include: 
The important thing to remember is that differential social class drop out occurs long before people apply to go to university. It happens at 16. That was true when the Robbins Committee reported in 1963 and it is still true.

The other factor that affects social class access is the width of the gate through which applicants have to pass. The narrower the gate the more the middle class gain. The wider the gate relatively more working class students enter. Robbins (1963) again showed this. The expansion of the 1990s had a similar result despite the possible adverse effects of the changes in funding. This shows how important it is to keep the gate wide.

The private rates of return gained by middle class children from staying on are less than those gained by working class children (Bennett, Glennerster and Nevison 1992). They already have parent and friend networks that give them privileged access to the labour market whether they went to university or not. Facing them with at least some of the costs of higher education may have deterred the marginal student and have done so quite appropriately. Already about four fifths of professional class children were going to university in the mid 1990s. ${ }^{2}$

Since this lecture was given the Government have announced a review of higher education finance and student support (Times Higher Education Supplement, October 5 2001). 
Table 11: Participation rates in higher education in Great Britain: by social class, 1991-99, \%

\begin{tabular}{lcccccccc}
\hline \hline & $1991 / 92$ & $1992 / 93$ & $1993 / 94$ & $1994 / 95$ & $1995 / 96$ & $1996 / 97$ & $1997 / 98$ & $1998 / 99$ \\
\hline Professional & 55 & 71 & 73 & 78 & 79 & 82 & 79 & 72 \\
Intermediate & 36 & 39 & 42 & 45 & 45 & 47 & 48 & 45 \\
Skilled non- & 22 & 27 & 29 & 31 & 31 & 32 & 31 & 29 \\
manual & 11 & 15 & 17 & 18 & 18 & 18 & 19 & 18 \\
Skilled manual & 12 & 14 & 16 & 17 & 17 & 17 & 18 & 17 \\
Partly skilled & 6 & 9 & 11 & 11 & 12 & 13 & 14 & 13 \\
Unskilled & 23 & 28 & 30 & 32 & 32 & 33 & 33 & 31 \\
All social classes & 23
\end{tabular}

Source: Social Trends Dataset, personal communication from ONS.

Note: The number of home domiciled initial entrants aged under 21 to full-time and sandwich undergraduate courses of higher education in further and higher education expressed as a proportion of the averaged 18-19 population. The 1991 Census provided the population distribution by social class for all years. This may have changed. If it has it is likely that the population base for the professional and managerial as well as the non-manual group will be higher than in 1991 - the manual group lower. This will over estimate the figures in the table for the manual groups and underestimate for the higher social groups.

\section{In Brief}

In brief we can say that in first four years of the Labour Government took a number of important policy initiatives but let education spending fall to its lowest point for four decades (For the historical figures see Glennerster 1997). Despite that, standards improved significantly in primary schools as a result of a series of measures begun by the previous government and pushed further by this one. Not only did average standards of achievement rise but the gap between the lowest achieving schools and the rest narrowed in terms of reaching target levels. So too did the gap between schools with many poor pupils and richer children's schools.

Performance by the end of secondary school has improved far less. The performance of schools in poor areas, or with a high percentage of poor pupils, is still dramatically below that of even the average school. It is here that our policy ingenuity has to be focused. There are some promising policies in the pipe line - maintenance grants for poor children to make staying on more financially attractive, vocational courses, bursaries for children from poor schools at university. But this 
nut will be harder to crack. We have done far too little to offset the incentives for schools to cream skim the most able or the least difficult to teach.

Important changes were made in the funding of higher education. Here the government got it partly right and partly wrong. Using the Inland Revenue as a way to collect back some of the gains the higher paid reap from the taxpayers' investment in them was a bold step that has worked. The pity is that the same principle was not applied to tuition fees. Here the Scots have got it more nearly right. Even here, though, the loan is interest free. This wastes part of the advantage in public spending terms and makes it less possible to use the extra revenue where it should be used - on raising the participation of those from poor families in higher education. 


\section{References}

Barr, N. (2001) The Welfare State as Piggy Bank: Information, Risk, Uncertainty, and the Role of the State. Oxford: Oxford University Press

Bennett, R., Glennerster, H. and Nevison, D. (1992) 'Investing in Skills: To Stay on or Not to Stay On', Oxford Review of Economic Policy, 8(2): 130-45

Burgess, R.L. (1997) 'Fiscal Reform and the Extension of Basic Health and Education Coverage' in C. Colclough (ed.), Marketising Education and Health in Developing Countries: Miracle or Mirage? Oxford: Oxford University Press

Burtless, G. (ed.) (1996) Does Money Matter?: The Effect of School Resources on Student Achievement and Adult Success. Washington DC: Brookings Institution

Chubb, J.E. and Moe, T.M. (1990) Politics, Markets and America's Schools. Washington DC: Brookings Institution

Dearing Committee (1997) Higher Education in the Learning Society. London: HMSO

Department for Education and Science (DfES) (2000) Departmental Report 2001. London: The Stationery Office

DfES, Statistical Bulletin, 04/98; 08/99; 03/00; 04/01, SRF40, available from DfES website

Gerwitz, S., Ball, S. and Bowe, R. (1995) Markets, Choice and Equity in Education. Buckingham: Open University Press

Glennerster, H. (1991) 'Quasi-markets for Education?', Economic Journal, 101(Sep): 1268-1276

Glennerster, H. (1997) Paying for Welfare: Towards 2000. Hemel Hempstead: Prentice Hall

Glennerster, H (1998) 'Education: Reaping the Harvest?', in Glennerster , H. and Hills J. (eds.) The State of Welfare: The Economics of Social Spending. Oxford: Oxford University Press

Glennerster, H., Wilson, G. and Merrett, S (1968) 'A Graduate Tax', Higher Education, 1(1): 26-38 
Gorard, S. and Fitz, J. (1998) ' Under starter's orders: the established market, the Cardiff study and the Smithfield project', International Studies in the Sociology of Education, 8: 365-376

Gundlach, E., Woessman, L. and Gmelin, J. (2001) 'The Decline of Schooling Productivity in OECD Countries', Economic Journal, 11(May): C135-C147

Hanushek, E.A. (1997) 'The productivity collapse in schools' in Fowler, W. (ed) Developments in School Finance 1996. Washington DC: US Department of Statistics, National Centre for Education Statistics (Also see Burtless op cit)

HM Treasury (2000) New Public Spending Plans 2001-2004, Cm 4807. London: The Stationary Office

Hobcraft, J. (2000) 'The Roles of Schooling and Educational Qualifications in the Emergence of Adult Social Exclusion', CASEpaper 43. London: London School of Economics

Independent Schools Information Service (ISIS) (2001) Personal communication

Ladd, H.F. (ed) (1996) Holding Schools Accountable: Performance-Based Reform in Education. Washington DC: Brookings Institution

Layard, R., McIntosh, S. and Vignoles, A. (2001) 'Britain's record on skills'. London: London School of Economics, Centre for Economic Performance

Lupton, R. (2001) 'Places Apart?: The Initial Report of CASE's Areas Study', CASEreport 14. London: London School of Economics

Machin, S. (1999) 'Wage inequality in the 1970s, 1980s and 1990s' in Gregg, P. and Wadsworth, J. (eds.) The State of Working Britain. Manchester: Manchester University Press

Mumford, K. (2001) 'Talking to Families in East London: A report on the first stage of research'. London: CASE, London School of Economics

Moser Report (1999) Improving literacy and numeracy: A fresh start. London: DfEE

Murname, R., Willett, J. and Levy, F. (1995) 'The Growing Importance of Cognitive Skills in Wage Determination', Review of Economics and Statistics, 251-64 
Naylor, R., Smith, J. and McKnight, A. (2001) 'Sheer Class: The extent and sources of variation in UK graduate earnings premium', forthcoming CASEpaper. London: London School of Economics

Office of National Statistics (1997a) Social Trends 1997. London: The Stationery Office

Office of National Statistics (1997b) Annual Abstract of Statistics. London: The Stationery Office

OECD (2001) Education at a glance: OECD Indicators. Paris: OECD

Robbins Committee (1963) Higher Education, Cmnd 2154. London: HMSO

Robertson, D. and Symons J. (1996) ‘Do Peer Groups Matter: Peer Group versus Schooling Effects on Academic Attainment' Centre for Economic Performance Paper DPO311 London: London School of Economics 


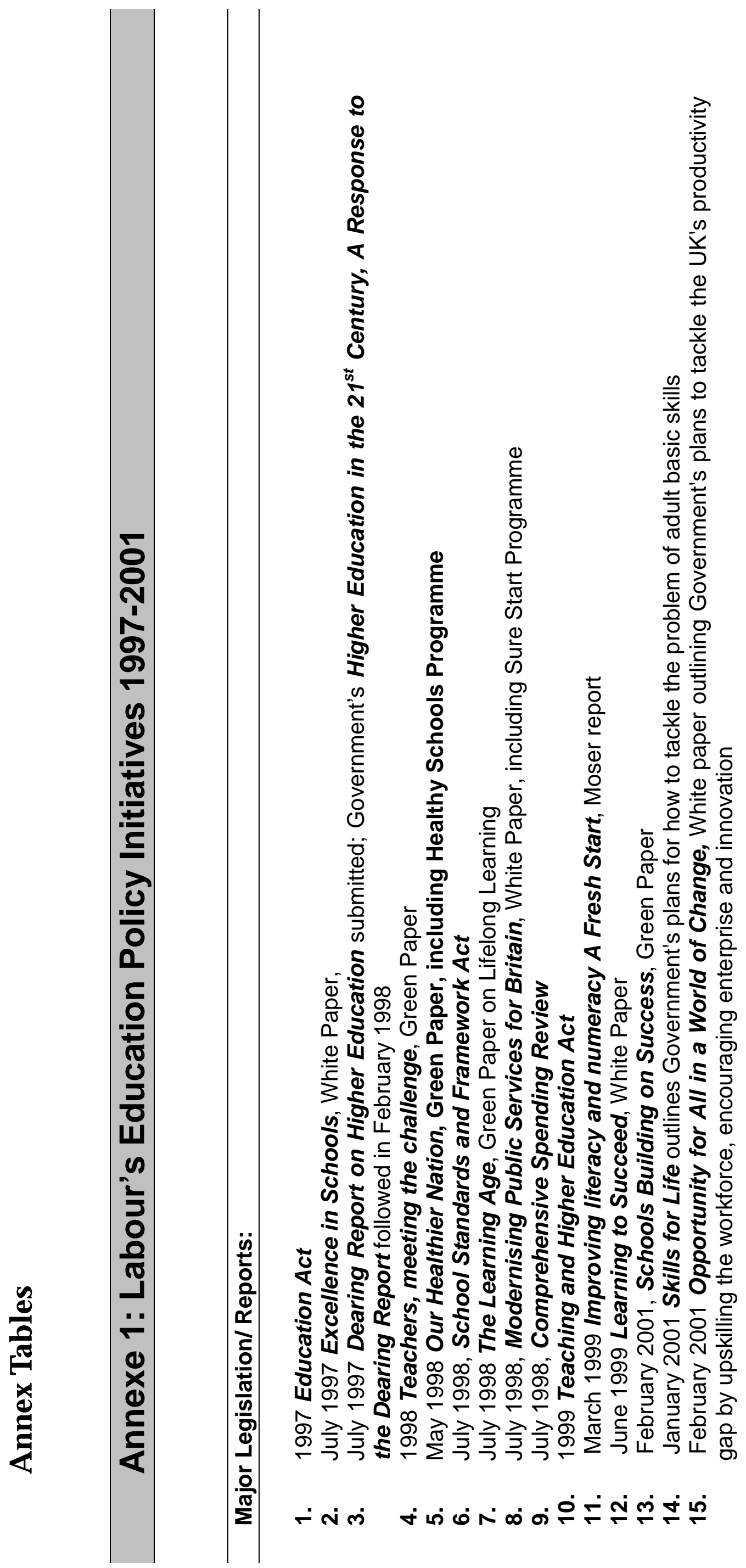




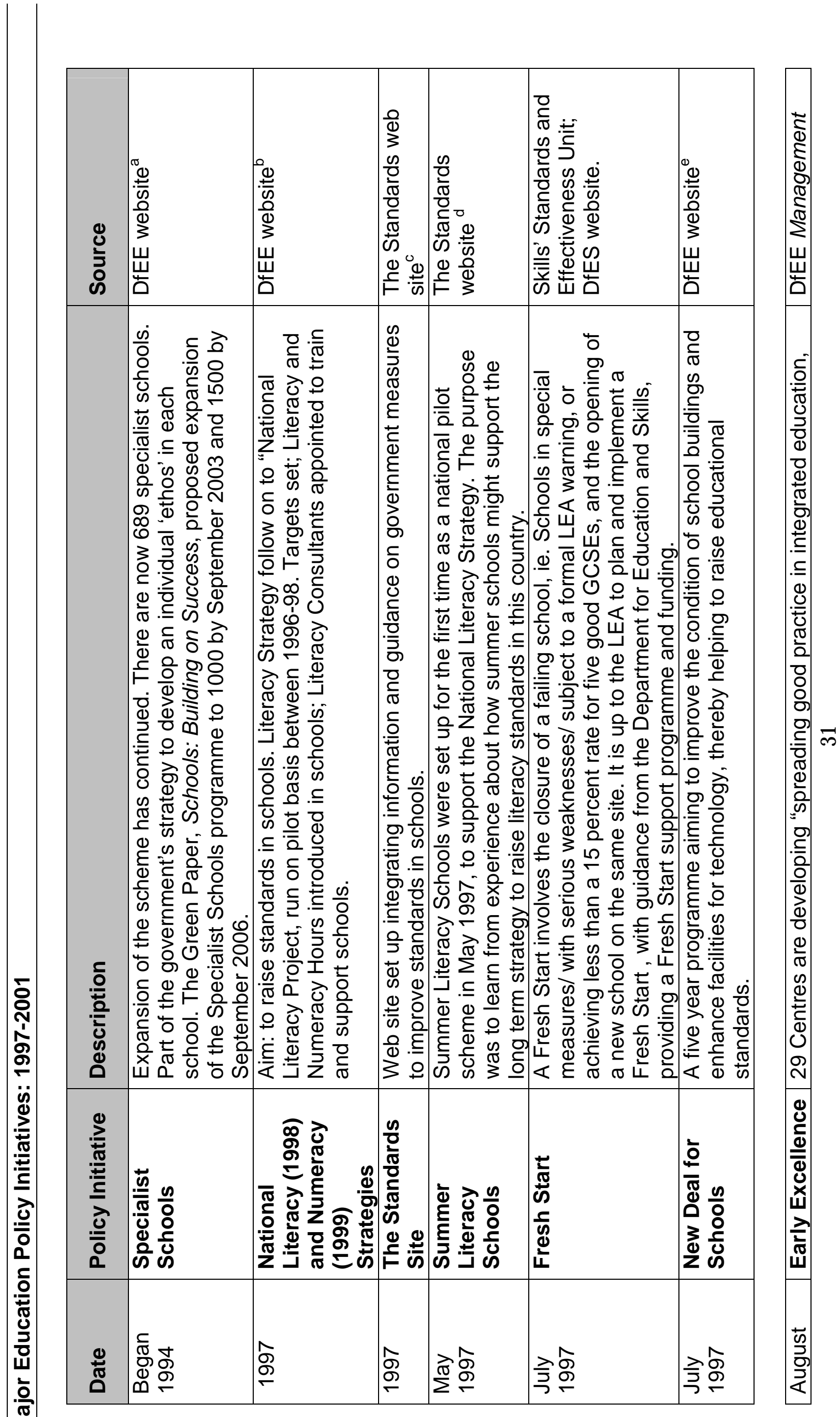




\begin{tabular}{|c|c|c|c|c|c|c|}
\hline 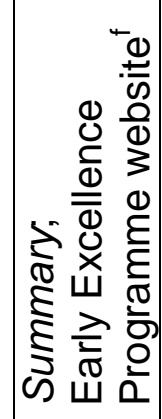 & 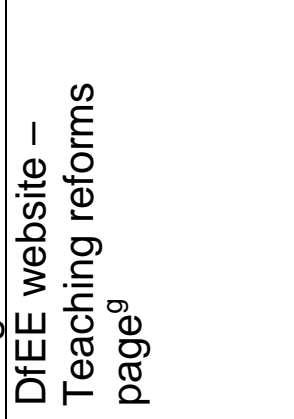 & 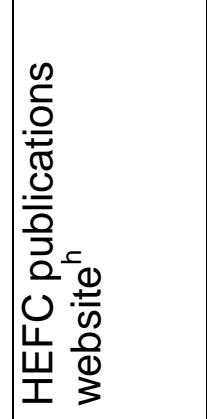 & 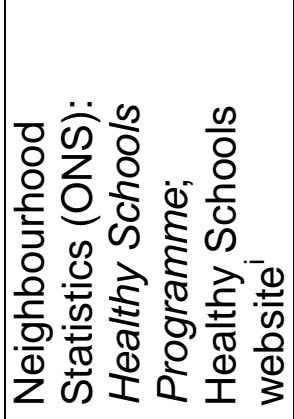 & 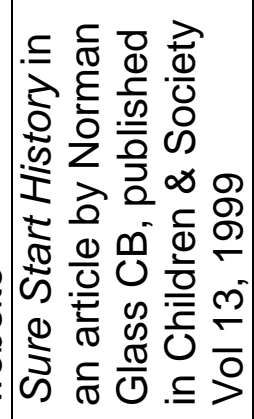 & 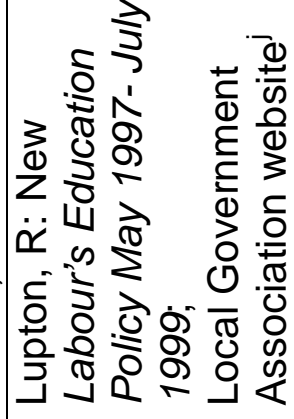 & 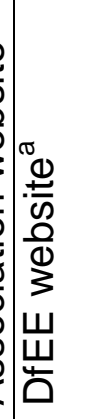 \\
\hline 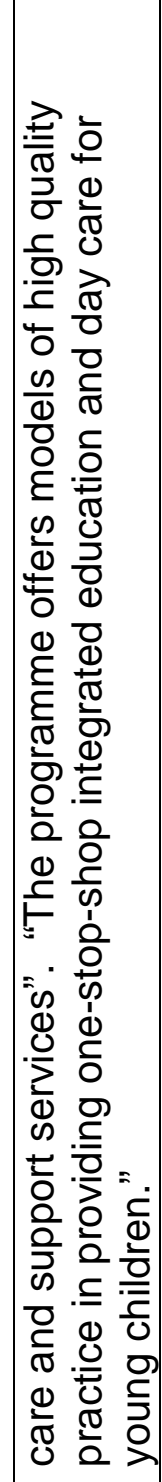 & 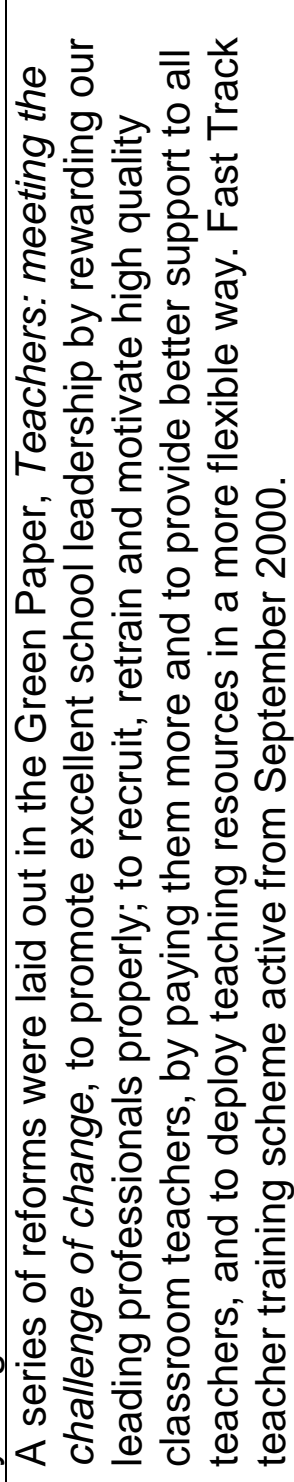 & 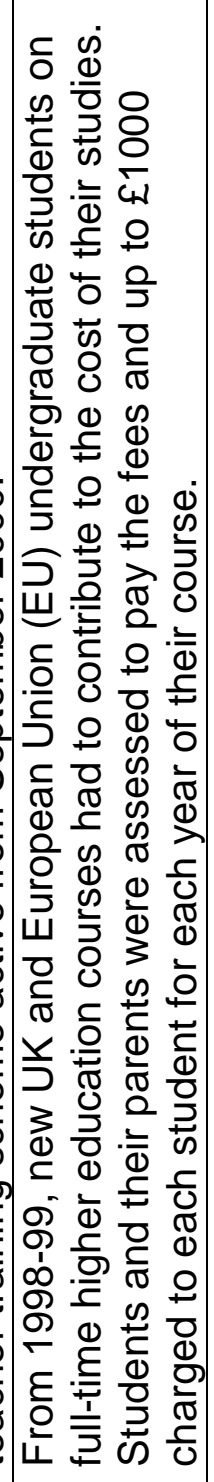 & 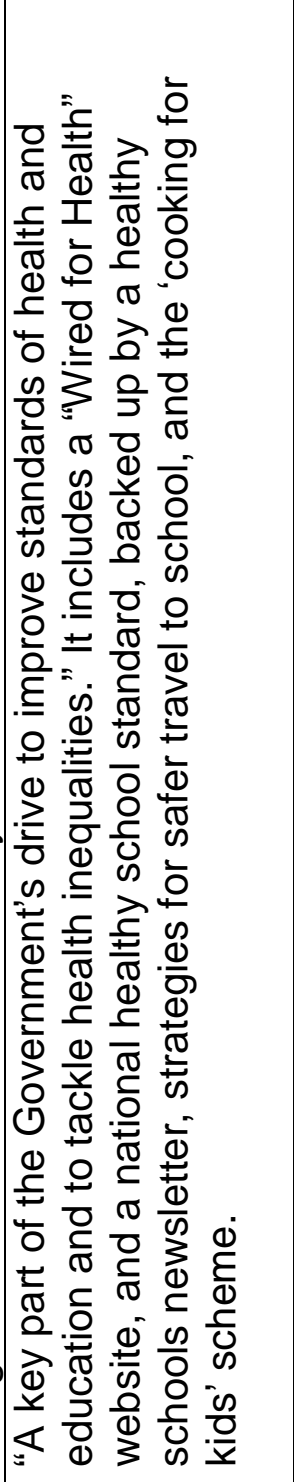 & 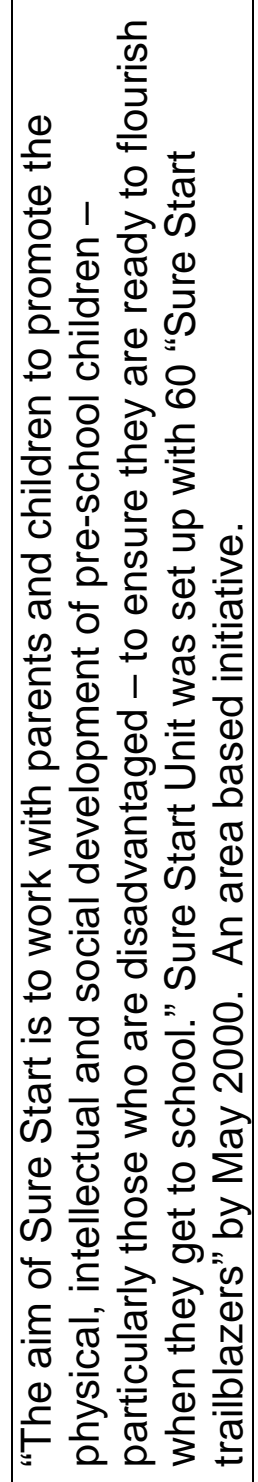 & 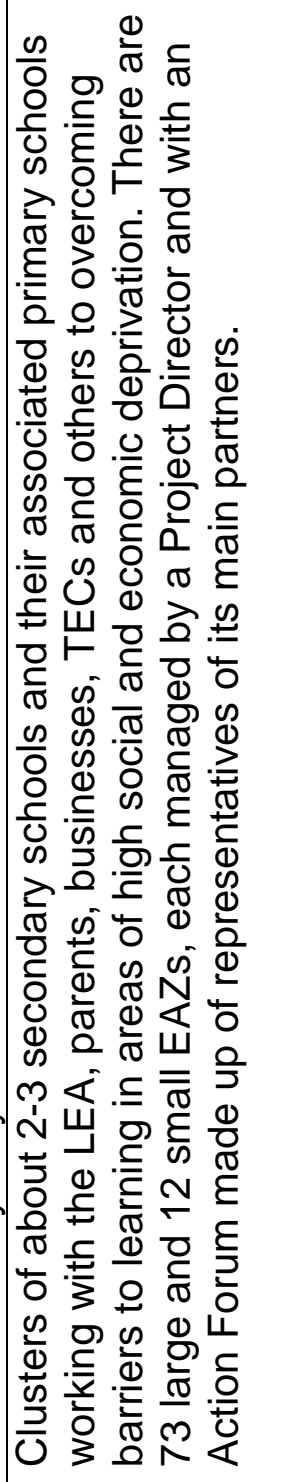 & 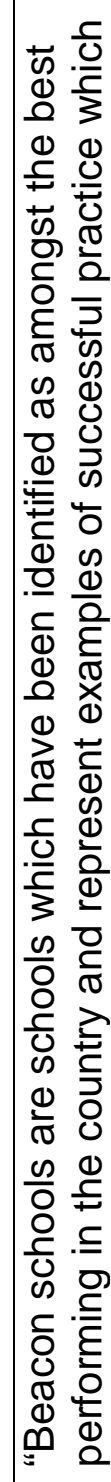 \\
\hline & 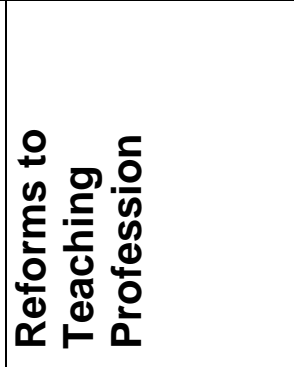 & 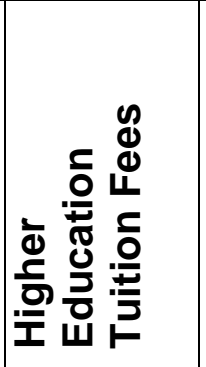 & 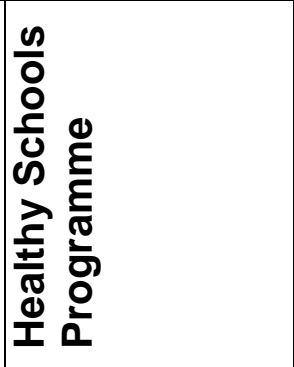 & 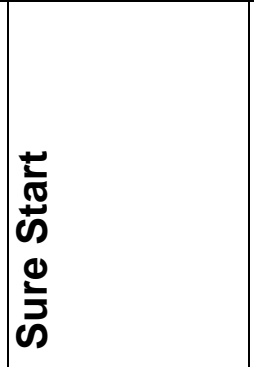 & 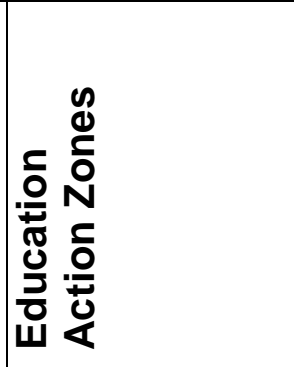 & 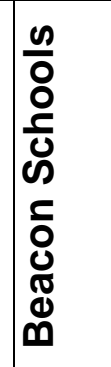 \\
\hline ब্তি & 吕 & 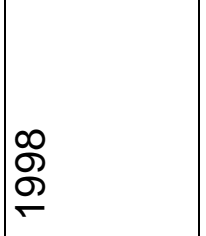 & ঝ্ত & 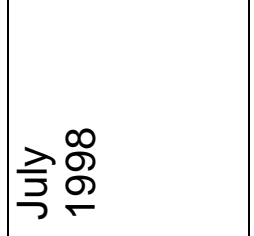 & 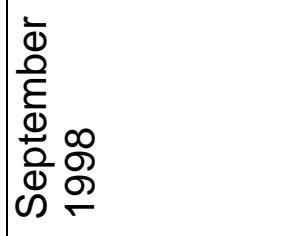 & 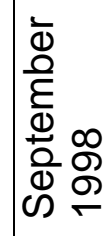 \\
\hline
\end{tabular}




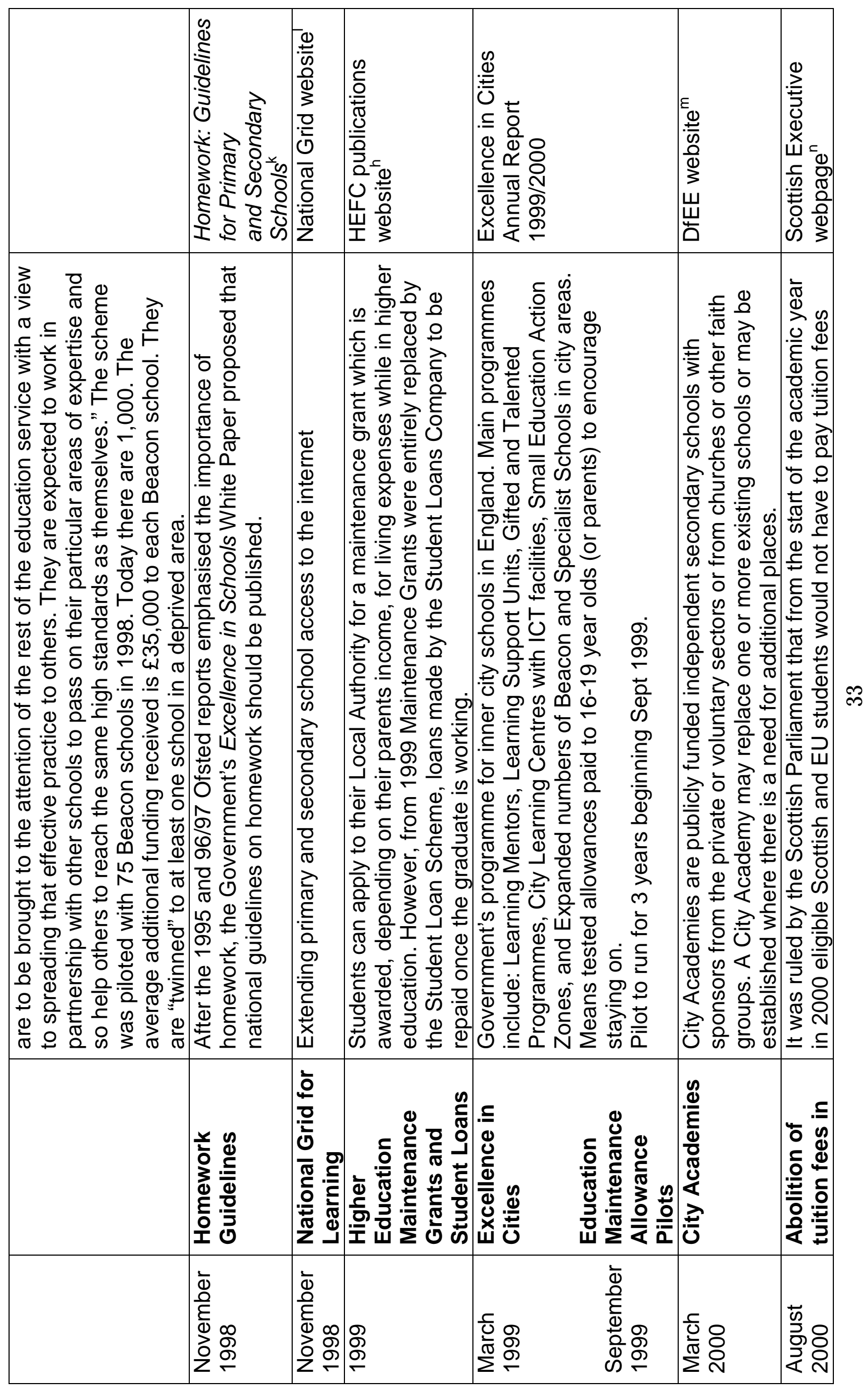




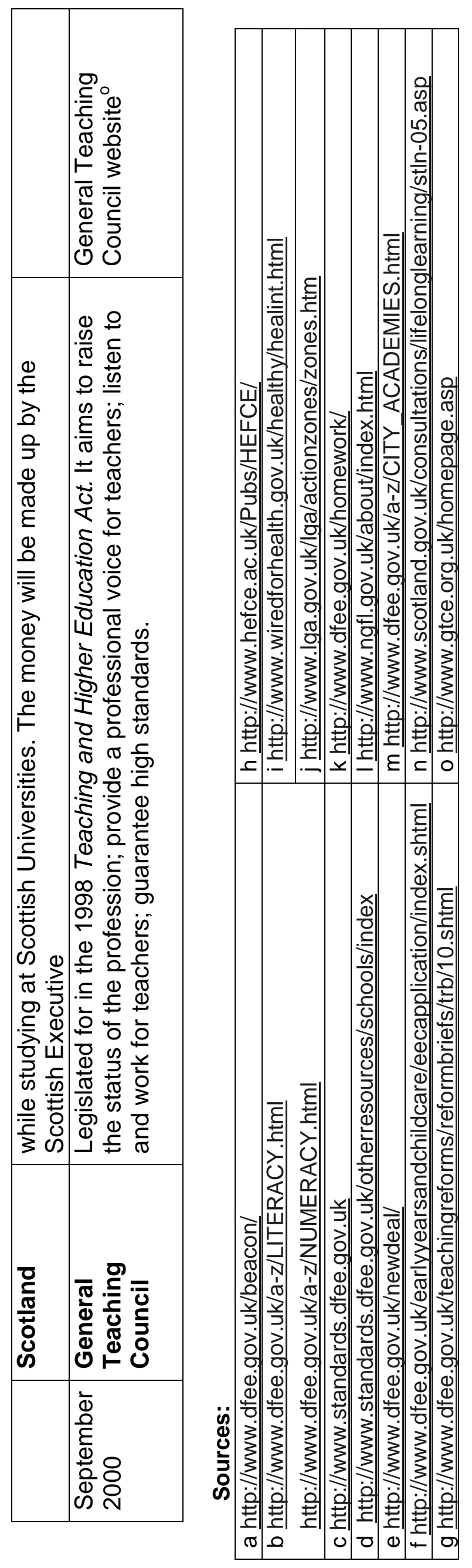




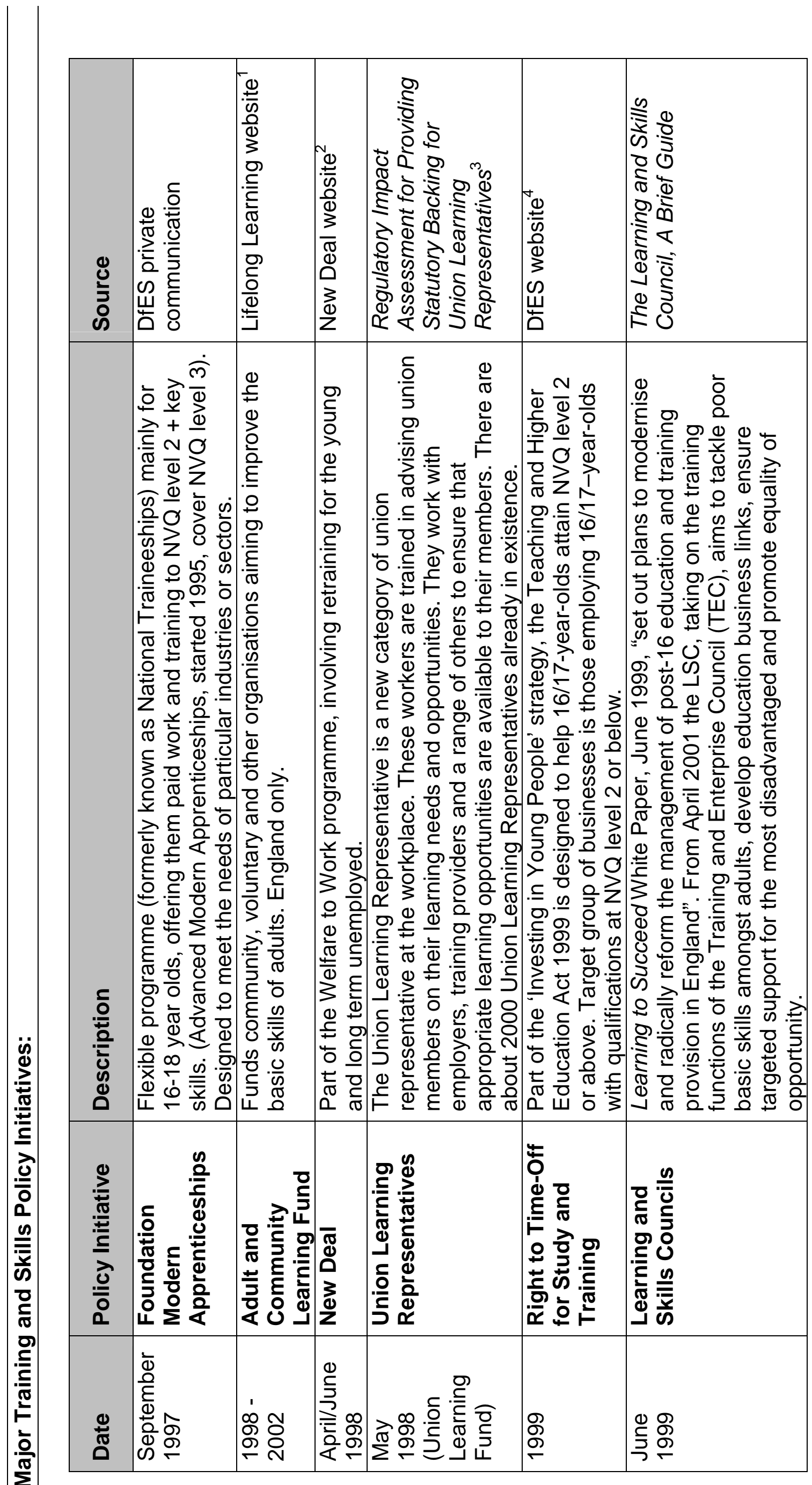




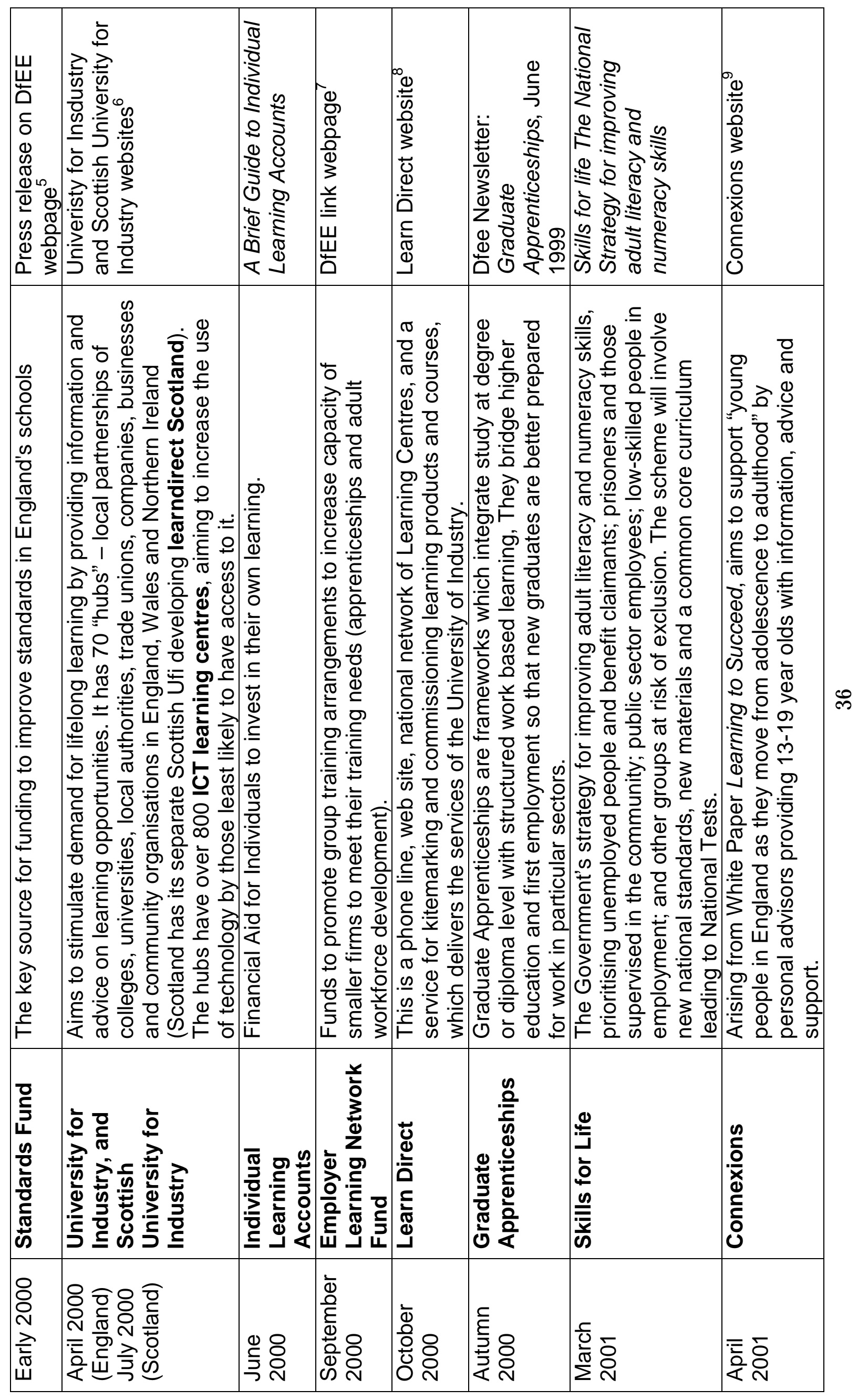




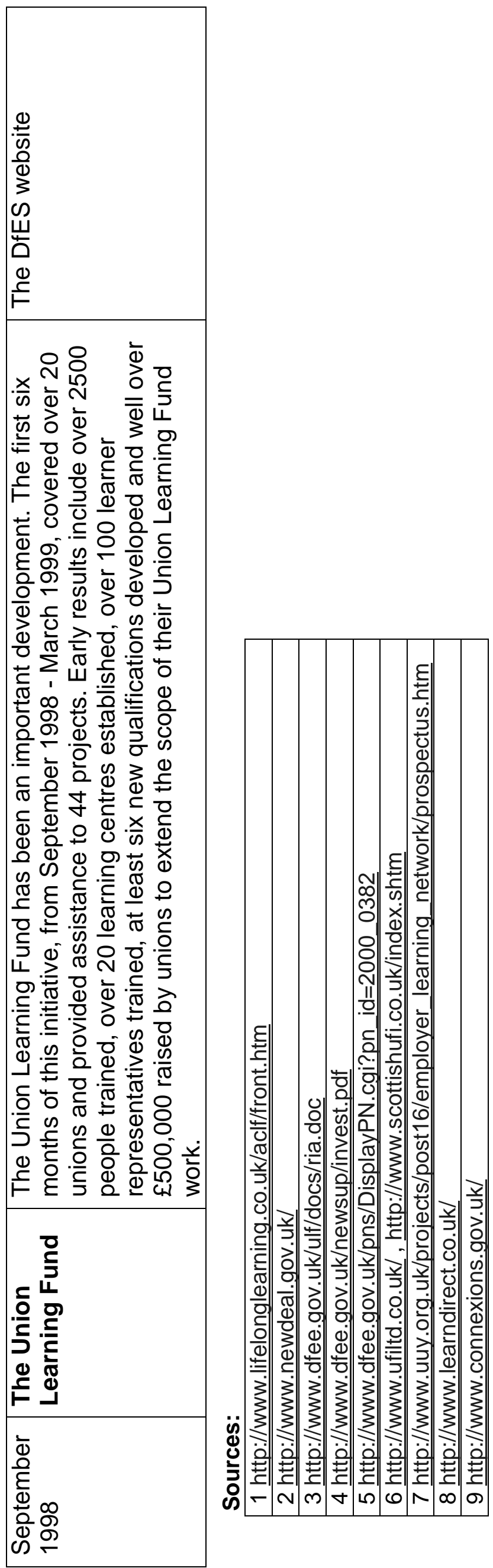




\section{Annexe 2: Tables}

Annexe Table 1: Children under five ${ }^{\mathrm{a}}$ in schools as a percentage of all children aged three and four, United Kingdom

\begin{tabular}{ll}
\hline \hline Year & Percentages \\
\hline $1970 / 71$ & 20.5 \\
$1975 / 76$ & 34.4 \\
$1980 / 81$ & 44.1 \\
$1985 / 86$ & 46.7 \\
$1990 / 91$ & \\
$1991 / 92$ & 51.6 \\
$1992 / 93$ & 52.6 \\
$1993 / 94$ & 54.6 \\
$1994 / 95$ & 55.4 \\
$1995 / 96$ & 56.7 \\
$1996 / 97$ & 57.4 \\
$1997 / 98$ & 58.4 \\
$1998 / 99$ & 61.0 \\
$1999 / 00$ & 63.8 \\
\hline \hline
\end{tabular}

Source: Department for Education and Employment; National Assembly for Wales;

Scottish Executive; Northern Ireland Department of Education

Note: (a) Pupils aged 3 and 4 at 31 December each year. Data for 1999/00 for Wales and Scotland relate to $1998 / 99$. 
Annexe Table 2: Participation Of 3-To-5year-Olds In Education, 1991, 1996/97, \%

\begin{tabular}{lcc|cc|cc}
\hline \hline & \multicolumn{3}{c}{ Age } & \multicolumn{5}{c}{} \\
\cline { 2 - 7 } & $\mathbf{3}$ & & $\mathbf{4}$ & & $\mathbf{5}$ & \\
\hline Belgium & 97 & 99 & 99 & 100 & 98 & 99 \\
France $^{(a)}$ & 98 & $100^{*}$ & 100 & $100^{*}$ & 99 & $100^{*}$ \\
Germany $^{\text {(a) }}$ & 35 & 58 & 71 & 81 & 84 & 84 \\
Netherlands & - & - & 98 & 99 & 99 & 99 \\
Spain & 28 & 67 & 94 & 99 & 100 & 100 \\
United & 32 & 48 & 72 & 94 & 100 & 99 \\
Kingdom & & & & & & \\
USA & 33 & & 57 & & 90 & \\
Canada & - & & 48 & & 70 & \\
Japan & 21 & & 58 & & 65 & \\
\hline \hline
\end{tabular}

Source for 1991 data: CSO

Source for 1996/7 data: Education across Europe statistics and indicators 1999, Copyright Eurostat

Note: * data for France 1996/97 is provisional/estimated

(a) data for 1996/7 includes students not allocated by ISCED level 
Annexe Table 3: Pupils in private schools as a percentage of school pupils

\begin{tabular}{lccccc}
\hline & 2-4 years & $\mathbf{5 - 1 1}$ years & $\mathbf{1 2 - 1 5}$ years & $\mathbf{1 6 - 1 8 ~ y e a r s ~}^{(\mathbf{b})}$ & $\begin{array}{c}\text { All school } \\
\text { pupils }\end{array}$ \\
\hline $1974 / 5^{(\mathrm{a})}$ & 2.0 & 3.2 & 7.0 & 11.4 & 5.5 \\
$1979 / 80$ & 4.8 & 4.5 & 6.9 & 18.3 & 5.8 \\
$1984 / 5$ & 4.8 & 5.0 & 7.4 & 17.5 & 6.2 \\
$1989 / 90$ & 5.7 & 5.1 & 7.7 & 16.9 & 6.7 \\
$1994 / 5$ & 5.6 & 4.7 & 7.3 & 18.4 & 6.3 \\
$1999 / 00^{(\mathrm{c})}$ & 6.0 & 5.0 & 6.7 & 16.5 & 6.2 \\
\hline \hline
\end{tabular}

Sources: Department for Education and Employment; National Assembly for Wales; Scottish Executive; Northern Ireland Department of Education

Notes: (a) On an England and Wales basis, on a UK basis in other years. (b) State pupils in 6th form and Further Education colleges are not included in these calculations. Source: DfEE, Table 12b (and Table 13 in earlier years). (c) 99/00 figures are provisional. Figures for Scotland are estimates using proportion of the stage rolls. Data for Wales are for 1998/99. Age at $31^{\text {st }}$ August 1999. 
Annexe TABLE 4: Gap Between The Scores Of Schools 1995-2000 (Maintained Schools) ${ }^{\star}$

\begin{tabular}{lccccc}
\hline \hline $\begin{array}{l}\text { Key Stage 1: } \\
7 \text { years, level 2+ }\end{array}$ & 1995 & 1997 & 1998 & 1999 & $\mathbf{2 0 0 0}$ \\
\hline $\begin{array}{l}\text { Reading } \\
75^{\text {th }} \text { percentile }\end{array}$ & 91 & 92 & 91 & 92 & 93 \\
$\quad$ Median & 82 & 83 & 83 & 85 & 86 \\
$25^{\text {th }}$ percentile & 71 & 73 & 73 & 75 & 77 \\
Writing & & & & & \\
$75^{\text {th }}$ percentile & 93 & 92 & 93 & 94 & 94 \\
Median & 84 & 84 & 85 & 86 & 88 \\
$25^{\text {th }}$ percentile & 73 & 73 & 74 & 76 & 78 \\
Maths & & & & & \\
$75^{\text {th }}$ percentile & 92 & 95 & 95 & 96 & 98 \\
Median & 83 & 88 & 88 & 90 & 93 \\
$25^{\text {th }}$ percentile & 71 & 78 & 79 & 82 & 86 \\
\hline \hline
\end{tabular}

Sources: DfES Statistical Bulletins: Table 5 4/98; Table 5 03/2000; Table 6 04/01 Note: * Figures are for the $75^{\text {th }}$ percentile school, median and $25^{\text {th }}$ percentile school. They show the \% of pupils in these schools who have reached the expected level.

Gap between top and bottom state school achievements narrowed in all three subjects and especially maths. There is a ceiling effect (top schools cannot go over 100\%) but that does not detract from the closing of the gap in absolute terms. 
Annexe Table 5: Gap Between The Scores Of Schools 1995-2000 (Maintained Schools)*

\begin{tabular}{lccccc}
\hline $\begin{array}{l}\text { Key stage 3: 14 years } \\
\text { Level 5+ }\end{array}$ & 1995 & 1997 & 1998 & 1999 & $\mathbf{2 0 0 0}$ \\
\hline $\begin{array}{l}\text { English } \\
75^{\text {th }} \text { percentile }\end{array}$ & 70 & 71 & 77 & 77 & 77 \\
$\quad$ Median & 55 & 58 & 65 & 64 & 65 \\
$\quad 25^{\text {th }}$ percentile & 38 & 43 & 52 & 51 & 51 \\
Maths & & & & & \\
$75^{\text {th }}$ percentile & 69 & 72 & 71 & 74 & 77 \\
$\quad$ Median & 58 & 61 & 60 & 63 & 66 \\
$25^{\text {th }}$ percentile & 44 & 47 & 46 & 50 & 53 \\
Science & & & & & \\
$75^{\text {th }}$ percentile & 68 & 74 & 69 & 68 & 73 \\
$\quad$ Median & 56 & 62 & 56 & 55 & 60 \\
$25^{\text {th }}$ percentile & 42 & 46 & 41 & 40 & 45 \\
\hline \hline
\end{tabular}

Note: * Figures are for the $75^{\text {th }}$ percentile school, median and $25^{\text {th }}$ percentile school. They show the \% of pupils in these schools who have reached the expected level.

Gap narrowed in English but not in Maths or Science. 


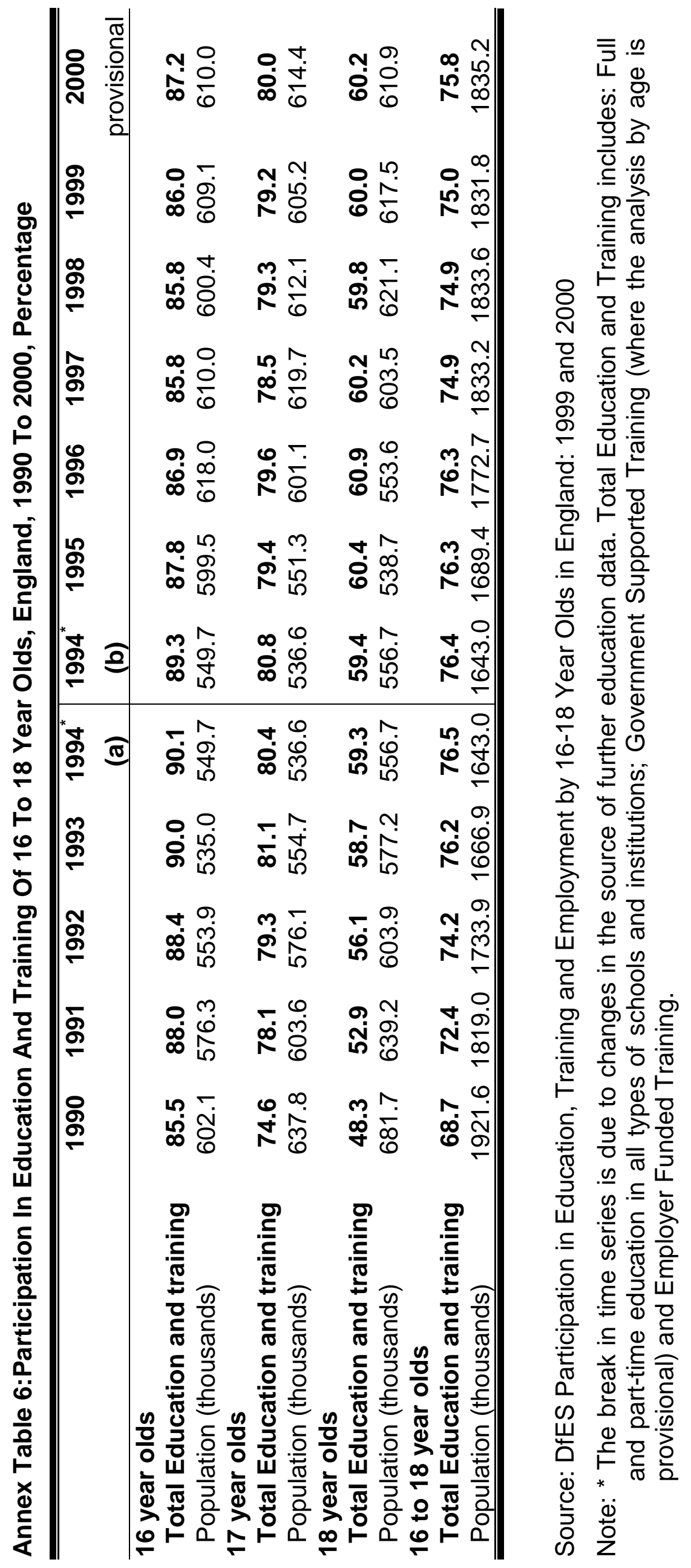

